\title{
PAJAK PERTAMBAHAN NILAI YANG DITANGGUNG OLEH PRODUSER FILM DALAM NEGERI DAN IMPORTIR FILM
}

\author{
Hazada Zafira Mauliza \\ hazadazafiramauliza@gmail.com, Politeknik Keuangan Negara STAN
}

\begin{abstract}
The purpose of this study is to understand the structure of costs and incomes of domestic film producers and film importers, as well as to understand the burden of value added tax borne by domestic film producers and film importers. The research method used is a literature study. The results of the study explain that the cost structure of domestic film producers is the cost of using services to facilitate film production activities which are included in services subject to value added tax. The cost structure of film importers is in the form of product prices and import duties. The income structure is in the form of income derived from profit sharing with cinema entrepreneurs on ticket sales. The value added tax burden borne by domestic film producers is equal to the input tax because it cannot be credited. There is no value added tax burden that must be borne by the film importer. The tax burden in the form of VAT which is an input tax for film importing companies can be credited with the output tax so that the VAT to be paid is nil and is no longer a tax burden for film importers.
\end{abstract}

Keywords : Film, Importir, Producer, Value added Tax

\begin{abstract}
Abstrak
Tujuan penelitian adalah memahami struktur biaya dan penghasilan produser film dalam negeri dan importir film, serta memahami beban pajak pertambahan nilai yang ditanggung oleh produser film dalam negeri dan impotir film. Metode penelitian yang digunakan adalah studi literatur. Hasil penelitian menjelaskan bahwa struktur biaya produser film dalam negeri adalah biaya atas pemanfaatan jasa-jasa untuk memperlancar kegiatan produksi film yang termasuk dalam jasa-jasa yang dikenakan pajak pertambahan nilai. Struktur biaya importir film berupa harga produk dan bea masuk. Adapun struktur penghasilannya berupa pendapatan yang diperoleh dari bagi hasil dengan pengusaha bioskop atas penjualan tiket. Beban pajak pertambahan nilai yang ditanggung oleh produser film dalam negeri adalah sebesar pajak masukannya karena tidak dapat dikreditkan. Tidak terdapat beban pajak pertambahan nilai yang harus ditanggung oleh importir film. Beban pajak berupa PPN yang merupakan pajak masukan bagi perusahaan importir film dapat dikreditkan dengan pajak keluarannya sehingga PPN yang harus dibayar nihil dan bukan lagi merupakan beban pajak bagi importir film.
\end{abstract}

Kata kunci : Film, Importir, Pajak pertambahan nilai, Produser

\section{PENDAHULUAN}

Berdasarkan Undang-Undang Nomor 33 Tahun 2009 tentang Perfilman, film adalah sebuah karya seni budaya yang merupakan suatu pranata sosial dan media komunikasi massa yang dibuat berdasar atas kaidah sinematografi dengan atau tanpa suara dan dapat dipertunjukkan. Film sebagai suatu pranata sosial dan media komunikasi massa membawa pesan yang berisi gagasan vital kepada publik dengan daya pengaruh yang besar sehingga film mempunyai fungsi pendidikan, hiburan, informasi, dan pendorong karya kreatif. Film juga memiliki dampak pada ekonomi yang mampu memajukan kesejahteraan masyarakat dengan memperhatikan prinsip persaingan usaha yang sehat. Dengan demikian, film menyentuh berbagai segi kehidupan manusia dalam bermasyarakat, berbangsa, dan bernegara.

Berdasarkan data statistik dan hasil survey ekonomi kreatif kerjasama Badan Ekonomi Kreatif (Bekraf) dengan Badan Pusat Statistik (BPS), industri perfilman sebagai salah satu subsektor ekonomi kreatif pada tahun 2015 berkontribusi sebesar 0,16\% terhadap Produk Domestik Bruto (PDB) Nasional atau senilai Rp1.363.200.000.000,00. Dari data ini terlihat bahwa industri perfilman belum berkontribusi secara signifikan terhadap perekonomian nasional, padahal industri ini memiliki multiplier effect yang berkontribusi tidak langsung (induced economic multiplier) yang cukup besar terhadap perekonomian. Salah satu dampak positif berupa kontribusi tidak langsung dari perkembangan industri perfilman adalah terhadap 
sektor pariwisata (film-induced tourism) yang akan mendorong perekonomian di lokasi pembuatan film. Dengan demikian, eksistensi industri perfilman sesungguhnya berkontribusi besar bagi perekonomian, baik secara langsung maupun tidak langsung.

Menurut Bekraf, industri perfilman dalam negeri berpotensi untuk dapat dikembangkan menjadi lebih baik walaupun para produser film dalam negeri masih harus menghadapi berbagai tantangan. Beberapa diantaranya adalah minimnya sumber daya manusia yang benarbenar mempunyai keahlian di bidang film sehingga pilihan untuk memperoleh tim dari sutradara, penulis skenario, kru, dan pemain film sangat terbatas, serta layar bioskop yang terbatas dan tidak merata penyebarannya.

Di samping itu, yang menjadi kendala berkembangnya industri perfilman dalam negeri adalah film dalam negeri masih kalah bersaing dengan film impor. Kementerian Pariwisata menyatakan bahwa jumlah film impor yang ditayangkan di bioskop mencapai 287 judul, sedangkan film dalam negeri hanya 105 judul. Film-film impor dan dalam negeri ini berebut jadwal tayang di 1.017 layar bioskop dalam negeri. Film-film dalam negeri harus turun dari jadwal tayang di bioskop karena peraihan jumlah penonton yang lebih sedikit jika dibandingkan dengan film-film impor. ${ }^{1}$ Sebagai media massa audio visual yang atraktif, menurut Handayani (2015: 1), film Indonesia sebenarnya sudah ada pada masa kolonial Belanda yang diatur dengan Film Ordonnantie 1940, selanjutnya pasca kemerdekaan diatur dengan Undang-Undang Nomor 1 Pnps Tahun 1964 tentang Pembinaan Perfilman, pada masa orde baru diatur dengan UndangUndang Nomor 8 Tahun 1992 tentang Perfilman, dan terakhir diatur dalam Undang-Undang Nomor 33 Tahun 2009 tentang Perfilman.

Sejarah produksi film dalam negeri berdasarkan keterangan Pandjaitan dan Aryanti (Dalam Ardiyono, 2015: 10-11) mengalami beberapa periode pasang surut dalam perkembangan dinamika keindustrian. Produksi judul film Indonesia pada tahun 1987 mencapai 124 judul, jumlah ini menurun menjadi 106 judul film di tahun 1989. Pada tahun 1990 terdapat kenaikan produksi sebanyak 115 judul, namun tahun 1999 hanya terdapat produksi sebanyak 4 judul film. Krisis pertama perfilman dalam negeri terjadi tahun 1957-1968 yaitu ketika para produser menyatakan menutup perusahaan dengan alasan bangkrut. Krisis kedua terjadi pada periode 1992-2002, menurut Alkahajar (2010: 13-16) industri perfilman Indonesia terbentur dengan perkembangan stasiun TV swasta, membanjirnya film impor, mutu film yang relatif rendah, perubahan tuntutan pasar mengenai tema yang ada dalam perfilman dalam negeri, dan pesatnya kemajuan industri audio visual khusunya home entertainment (kaset video, laser disk, video compact disk/VCD, dan digital video disk/DVD).

Perusahaan-perusahaan pemesan film impor di Indonesia atau importir film banyak bermunculan sekitar tahun 1980an. Banyak bioskop-bioskop yang menayangkan film Hollywood, Hongkong, dan India. Bioskop-bioskop tersebut juga berperan sebagai importir atau pemesan film. Pada Maret 2011, The Motion Picture Association of America (MPAA) sebagai pemegang tunggal hak distribusi dari 6 studio film Hollywood berencana tidak mendistribusikan beberapa judul film box office untuk diimpor ke Indonesia. Menurut Ilham Bintang (Dalam Azanda, 2012: 3) bahwa "hal ini dipicu oleh penerbitan Surat Edaran Direktur Jenderal Pajak Nomor SE-03/PJ/2011 tentang PPh atas Penghasilan berupa Royalti dan perlakuan PPN atas pemasukan film impor." Importir film dan pihak MPAA tidak setuju dengan penetapan royalti atas pemasukan film impor. Sriyanto (2016: 97) menyatakan bahwa diperkirakan selama ini MPAA dan importir film telah keliru memberitahukan pajak terutang (self assesment) dengan melaporkan penghitungan bea masuk berdasarkan panjang film tanpa

1 Angga Rulianto. 2014. Film Indonesia Masih Jadi Anak Tiri. Dalam http://www.muvila.com/film/artikel/film-indonesia-masih-jadi-anak-tiri-1408117.html, diakses pada tanggal 21 September 2017. 
memasukkan komponen lain dalam penghitungan nilai pabean dan Pajak Dalam Rangka Impor (PDRI) yaitu royalti yang dikenakan atas pemasukan film impor.

Dari sisi jumlah film yang beredar di dalam negeri, sebagaimana terlihat pada grafik 1 , produksi film dalam negeri berbeda jauh jumlahnya dibandingkan dengan jumlah film impor yang beredar di Indonesia. Pada periode 1999-2016, rata-rata jumlah produksi film dalam negeri hanya mencapai 56 judul film per tahun, sedangkan film impor mencapai 218 judul film per tahun. Jumlah produksi film dalam negeri terbanyak adalah pada tahun 2015 yaitu 129 judul film, sedangkan jumlah produksi film impor terbanyak adalah pada tahun 2007 yaitu 296 judul film.

\section{Grafik 1 Jumlah Produksi Film di Indonesia}

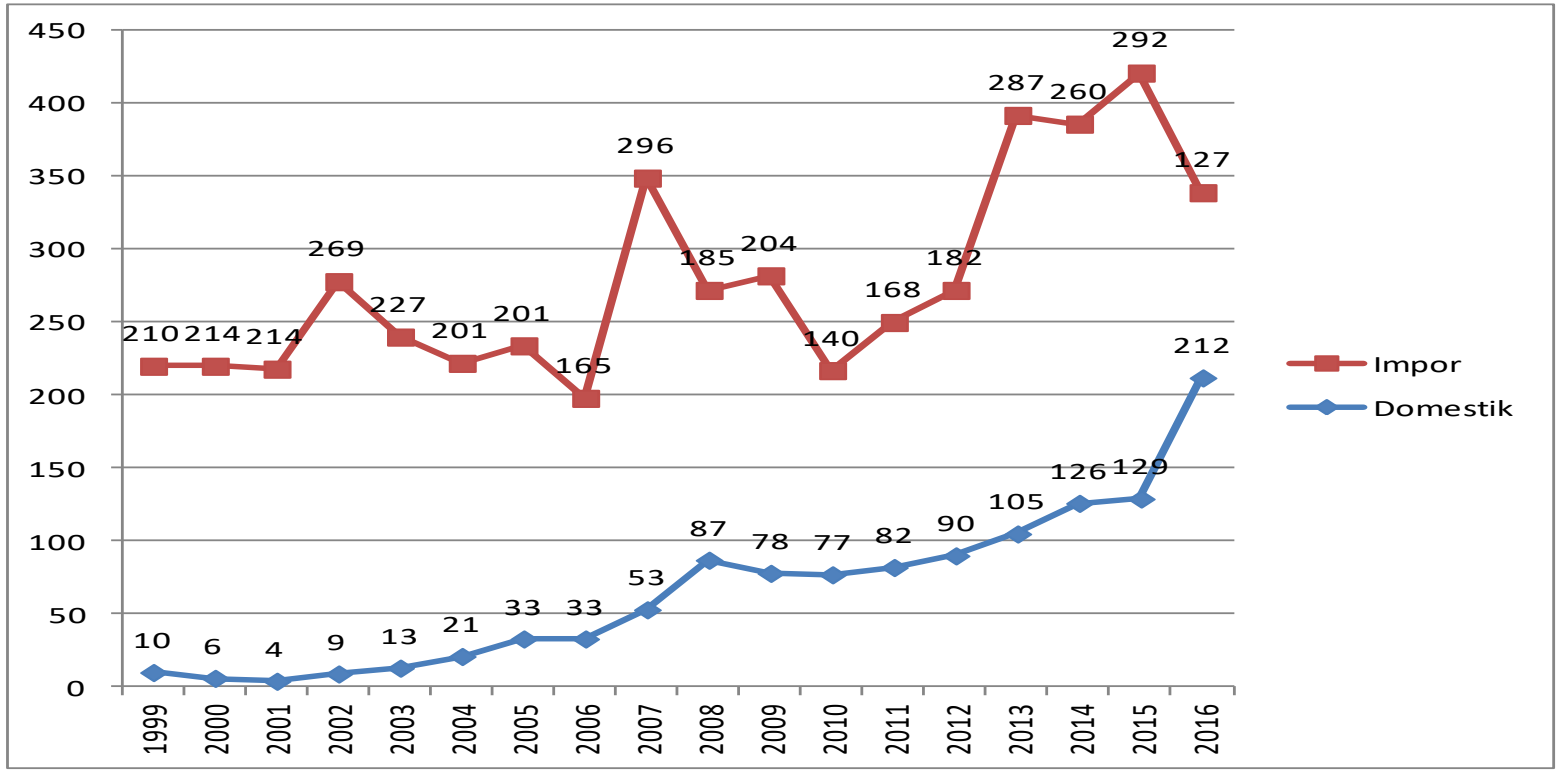

Sumber: Depdikbud (Dalam Damayanty dan Setiawan, 2017: 50)

Menurut Damayanty dan Setiawan (2017: 47) adanya penelitian yang komprehensif atas industri perfilman pada suatu negara mengindikasikan adanya dukungan pemerintah terhadap perkembangan industri yang dimaksud, walaupun di sisi nominal kontribusi langsung terhadap PDB masih berada di bawah 1 persen.

Tabel 1 Kontribusi Industri Perfilman terhadap Perekonomian Beberapa Negara

\begin{tabular}{|c|c|c|c|c|c|}
\hline & China, & Korea Selatan, & Kanada, & $\mathbf{U K}$ & Indonesia, \\
\hline & $2014^{1}$ & $\mathbf{2 0 1 1}^{2}$ & $\mathbf{2 0 1 1}^{3}$ & $2006^{4}$ & $\mathbf{2 0 1 5}^{5}$ \\
\hline \multicolumn{6}{|l|}{ Kontribusi Langsung } \\
\hline - Nominal & $\begin{array}{r}146 \text { miliar } \\
\text { Yuan }\end{array}$ & $\begin{array}{r}7.549 \text { miliar } \\
\text { KRW }\end{array}$ & $\begin{array}{r}20,4 \text { miliar } \\
\text { CAD }\end{array}$ & $\begin{array}{r}1,5 \text { miliar } \\
\text { Pound }\end{array}$ & $\begin{array}{r}\text { Rp1.363,2 } \\
\text { miliar }\end{array}$ \\
\hline $\begin{array}{l}\text { - Persentase terhadap } \\
\text { PDB } \\
\end{array}$ & 0,2 & 0,7 & tidak tersedia & $\begin{array}{r}\text { tidak } \\
\text { tersedia }\end{array}$ & 0,16 \\
\hline - Tenaga Kerja & 970.000 & 67.267 & 262.700 & 33.500 & tidak tersedia \\
\hline - Pendapatan Pajak & $\begin{array}{r}39 \text { miliar } \\
\text { Yuan }\end{array}$ & $\begin{array}{r}3.752 \text { miliar } \\
\text { KRW }\end{array}$ & $\begin{array}{r}5,5 \text { miliar } \\
\mathrm{CAD}\end{array}$ & $\begin{array}{r}436 \text { juta } \\
\text { Pound }\end{array}$ & tidak tersedia \\
\hline \multicolumn{6}{|c|}{ Induced Economic Multiplier } \\
\hline - Nominal & $\begin{array}{r}396 \text { miliar } \\
\text { Yuan }\end{array}$ & $\begin{array}{r}17.454 \text { miliar } \\
\text { KRW }\end{array}$ & tidak tersedia & $\begin{array}{r}4,3 \text { miliar } \\
\text { Pound }\end{array}$ & tidak tersedia \\
\hline $\begin{array}{l}\text { - Persentase terhadap } \\
\text { PDB } \\
\end{array}$ & 0,6 & 1,6 & tidak tersedia & $\begin{array}{r}\text { tidak } \\
\text { tersedia }\end{array}$ & tidak tersedia \\
\hline - Tenaga Kerja & 4,1 juta & 299.100 & tidak tersedia & 94.700 & tidak tersedia \\
\hline - Pendapatan Pajak & $\begin{array}{r}104 \text { miliar } \\
\text { Yuan }\end{array}$ & $\begin{array}{r}5,515 \text { miliar } \\
\text { KRW }\end{array}$ & tidak tersedia & $\begin{array}{r}1,1 \text { miliar } \\
\text { Pound }\end{array}$ & tidak tersedia \\
\hline
\end{tabular}

Sumber:

${ }^{1}$ Oxford Economics (Dalam Damayanty dan Setiawan, 2017: 47)

${ }^{2}$ Oxford Economics (Dalam Damayanty dan Setiawan, 2017: 47) 
${ }^{3}$ Motion Pictures Association-Canada (Dalam Damayanty dan Setiawan, 2017: 47)

${ }^{4}$ Oxford Economics (Dalam Damayanty dan Setiawan, 2017: 47)

${ }^{5}$ Diolah dari Bekraf (2017: 5)

Pada tabel di atas disajikan bahwa industri perfilman di Korea Selatan berkontribusi secara signifikan terhadap perekonomian di negaranya termasuk kontribusi tidak langsung sebesar 1,6 persen terhadap PDB. Industri perfilman di China berkontribusi langsung sebesar 0,2 persen terhadap PDB dan berkontribusi tidak langsung sebesar 0,6 persen terhadap PDB. Berdasarkan data statistik dan hasil aurvey ekonomi kreatif kerja sama Badan Ekonomi Kreatif (Bekraf) dengan Badan Pusat Statistik (BPS), pada tahun 2015 industri ekonomi kreatif di Indonesia menyumbangkan Rp852 triliun terhadap PDB Nasional (7,38\%), menyerap 15,9 juta tenaga kerja $(13,90 \%)$, dan menghasilkan nilai ekspor US $\$ 19,4$ miliar $(12,88 \%)$. Industri perfilman di Indonesia sebagai salah satu dari 16 subsektor industri kreatif berkontribusi sebesar Rp1.363.200.000.000 terhadap PDB Nasional (0,16\%). Walaupun kontribusi langsung industri perfilman terhadap perekonomian belum berpengaruh secara signifikan, industri perfilman memiliki efek ganda terhadap perekonomian berupa kontribusi tidak langsung (induced economic multiplier) misalnya mendorong perkembangan sektor pariwisata di lokasi pembuatan film dalam negeri maupun luar negeri.

Dari aspek perpajakan, terdapat peraturan perpajakan yang perlu dipertimbangkan untuk diperbaiki agar dapat menyesuaikan dengan keadaan perekonomian dan industri perfilman dalam negeri. Mahira (2012: 79) menyebutkan bahwa salah satu masalah terbesar yang dikeluhkan oleh produser film dalam negeri adalah tidak bisa dilakukannya pengkreditan pajak masukan dari PPN atas jasa-jasa yang digunakan untuk memproduksi film dalam negeri dengan pajak keluaran dari PPN atas penyerahan film dalam negeri ke bioskop sebagaimana diatur dalam Surat Edaran Direktur Jenderal Pajak Nomor SE-30/PJ.3/1987 tentang PPN atas Film Ceritera Produksi Dalam Negeri (Film Nasional). Produser film dalam negeri merasa sangat dirugikan dengan tidak bisa dikreditkannya pajak masukan dengan pajak keluaran tersebut karena PPN terutang yang dibayarkan oleh produser film dalam negeri untuk jasa-jasa yang dimanfaatkan berkaitan dengan kegiatan memproduksi film dalam negeri jumlahnya cukup besar. Tujuan penelitian adalah memahami struktur biaya dan penghasilan produser film dalam negeri dan importir film, serta memahami beban pajak pertambahan nilai yang ditanggung oleh produser film dalam negeri dan impotir film.

\section{KAJIAN PUSTAKA}

\section{Pelaku Industri Perfilman di Indonesia}

Berdasarkan Undang-Undang Nomor 33 Tahun 2009 tentang Perfilman, bentuk kegiatan pelaku industri perfilman di Indonesia terdiri atas : (a) kegiatan perfilman, yaitu penyelenggaraan perfilman yang langsung berhubungan dengan film dan bersifat non komersial. (b) usaha perfilman, yaitu penyelenggaraan perfilman yang langsung berhubungan dengan film dan bersifat komersial. Dari kedua jenis pelaku industri perfilman di atas, pembahasan dibatasi pada Pelaku Usaha Pembuatan Film (Produser Film Dalam Negeri), Pelaku Usaha Pengedaran Film (Distributor), Pelaku Usaha Pertunjukan Film (Pengusaha Bioskop), dan Pelaku Usaha Impor Film (Importir Film) atas penyerahan film dalam negeri dan film impor kepada pengusaha bioskop di seluruh Indonesia. Berikut merupakan pelaku industri perfilman di Indonesia:

\section{Produser film dalam negeri}

Pelaku usaha pembuatan film merupakan badan usaha yang berbadan hukum Indonesia. Perusahaan produksi film di Indonesia terdiri atas sineas industri jalur utama (mainstream) dan jalur kiri/indie (sidestream). Sullivan,dkk (Dalam Suwardi, 2017: 3) mengemukakan bahwa “... produksi media secara mainstream adalah penggolongan berdasarkan peningkatan 
konsentrasi kepemilikan". Penjelasan mengenai konsentrasi kepemilikan dalam produksi media secara mainstream dilengkapi dengan pendapat Albarran (Dalam Suwardi, 2017: 3-4) sebagai konsentrasi kepemilikan dalam produksi media secara mainstream tidak hanya dominan pada satu faktor, tetapi terjadi praktek penguasaan dari hulu ke hilir atau dalam konteks ekonomi media praktek ini disebut dengan Vertical Integration. Vertical Integration yaitu saat suatu perusahaan mengendalikan berbagai aspek, baik produksi, distribusi, dan ekshibisi sebuah produk.

Dalam penelitiannya mengenai distribusi film independen, Suwardi (2017: 4) menyatakan bahwa produksi media jalur sidestream di Indonesia adalah jika di Indonesia, film independen bergerak secara mandiri dengan dana yang seadanya sesuai dengan kreativitas film maker dalam mencari funding, kru yang belum tentu dibayar, lalu mendistribusikan film secara door-to-door agar mendapatkan penonton alih-alih mendapatkan pemasukan untuk produksi selanjutnya. Perbedaan mendasar antara jalur utama (mainstream) dan jalur kiri (sidestream) adalah pada media yang digunakan untuk mengekspolitasi film yang telah diproduksi. Pembahasan mengenai produser film dalam negeri dibatasi pada industri jalur utama (mainstream) atas produksi film dalam negeri yang akan dipertunjukkan di bioskop.

Berbeda dengan industri sinema Amerika Serikat atau yang secara umum disebut Hollywood, produser film di Indonesia tidak hanya dikuasai oleh studio-studio besar seperti Walt Disney Pictures, Warner Bros Pictures, Universal Pictures, 20th Century Fox, Columbia Pictures, dan Paramount Pictures. Setidaknya tercatat empat puluh produser film di Indonesia. Sebagian besar produser-produser tersebut tergabung dalam Persatuan Perusahaan Film Indonesia (PPFI) yang didirikan di Jakarta, sejak 16 Juli 1956.

Pembuatan film oleh produser film harus didahului dengan menyampaikan pemberitahuan pembuatan film kepada Menteri dengan disertai judul film, isi cerita, dan rencana pembuatan film. Pembuatan film dapat dilakukan dengan teknologi analog, digital, atau teknologi tertentu dan direkam pada pita seluloid, pita video, cakram optik, atau bahan lainnya. Pembuatan film dapat melalui proses kimia, elektronik, atau proses lainnya. Film yang diproduksi dapat berupa film cerita atau film non cerita. Film cerita adalah semua film yang mengandung cerita, termasuk film eksperimental dan film animasi. Film non cerita adalah semua film yang berisi penyampaian informasi, termasuk film animasi, film iklan (film yang memuat materi iklan), film eksperimental, film seni, film pendidikan, dan film dokumenter. Bentuk film tersebut tidak termasuk berita dan materi siaran langsung yang disiarkan oleh lembaga penyiaran televisi.

Rantai produksi film dimulai dari pemilihan ide cerita hingga film selesai diproduksi dan siap didistribusikan. Pihak-pihak yang terlibat dalam rantai produksi adalah semua kru, pemain film, perusahaan penyewaan alat, lembaga sensor film dan lembaga bahasa sebagai mitra konsultasi naskah film. Di dalam buku Panduan Pendirian Usaha Pembuatan Film yang disusun oleh Bekraf dijelaskan bahwa rantai produksi film dimulai dari tahap pengembangan yaitu penentuan rencana dan tujuan film diproduksi termasuk bagaimana film yang diproduksi didanai dan dipasarkan. Rencana disusun berdasarkan jenis film yang akan diproduksi, durasi film, lokasi film, peralatan yang diperlukan, awak film yang akan dilibatkan, dan perizinan. Dalam tahap praproduksi sutradara dan seluruh awak film memastikan bahwa semua kebutuhan produksi film telah sesuai dan siap mendukung produksi film: peralatan (gear), set, artistic, dressing, wardrobe, make up, dan budget.

Setelah seluruh persiapan produksi film matang, proses produksi dilanjutkan dengan pelaksanaan shooting dengan memerhatikan teknik pencahayaan dan peralatan yang dibutuhkan, aspek audio dalam perekaman film, teknik sinematografi, penyusunan jadwal break dalam kurun waktu tertentu, kepiawaian sutradara dan pemain film dalam menjalankan perannya, dan ketersediaan prosedur kerja masing-masing awak film agar tahapan produksi 
film dapat berjalan lancar dan efektif. Tahap pascaproduksi dilakukan untuk memastikan film yang dibuat memvisualisasikan cerita yang telah disusun dalam naskah, yaitu dengan pengeditan bagian film yang kurang maksimal, pengeditan suara agar selaras dengan jalan cerita, penyesuaian musik dengan situasi dalam adegan pada film, pengeditan dialog, dan penambahan efek suara.

\section{Distributor}

Proses distribusi merupakan tahap lanjutan setelah film selesai diproduksi. Distribusi merupakan salah satu kegiatan ekonomi sebuah film yang terdiri atas produksi-distribusikonsumsi. Sasono et.al. (2011: 191) menyatakan bahwa "Distribusi film merupakan 'seni yang tak tampak', karena sepenuhnya berjalan di belakang layar, jauh dari hiruk pikuk produksi dan sorotan publik di tahap ekshibisi". Pengertian proses distribusi didasarkan pada pendapat Knight and Thomas (Dalam Suwardi, 2017: 2) adalah sebuah rantai yang tidak terlihat yang menghubungkan antara produksi film dan pemutaran film, di dalam mekanisme kegiatan ekonomi film proses ini berada pada lini yang sangat penting untuk menarik perhatian penonton. Namun, dengan praktik promosi dan pemasaran, kebijakan akuisisi, dan hubungan dengan pihak produsen dan ekshibitor, distributor memegang peran yang krusial dalam menentukan film apa yang akan dilihat oleh penonton dan dalam rangka membentuk budaya yang didapat dari film.

Distributor atau perusahaan distribusi film merupakan pihak yang menyalurkan film ke jaringan bioskop, televisi, dan home video. Sasono et.al. (2011: 192-193) menyatakan bahwa distribusi memastikan mekanisme pasar berjalan, karena hanya lewat peran distribusilah terjadi arus barang dan jasa, dengan asumsi distribusi terjadi di sebuah pasar yang terbuka. Dalam menentukan jumlah kopi film, distributor mempertimbangkan pangsa pasar, lokasi penayangan, waktu rilis hingga analisis kekuatan film yang akan didistribusikan. Pihak distributor mengadakan kesepakatan dengan berbagai pihak di sisi hulu dan hilirnya untuk menentukan mekanisme eksploitasi karya film sehingga hasilnya dapat menguntungkan semua pihak. Distributor berwenang untuk mengeksploitasi film dengan metode yang disepakati. Distributor membeli hak eksploitasi dari produser film dengan kemungkinan satu dari tiga mekanisme, yaitu: (1) sistem beli putus, (2) komisi setelah menjualkan; atau (3) bagi hasil (profit sharing). Cara menjual hak tayang film ke pengusaha bioskop dilakukan dengan dua cara, yaitu: (1) harga pasti (umumnya lewat pelelangan); atau (2) bagi hasil. Pada umumnya, cara yang digunakan adalah sistem bagi hasil karena dapat membangun hubungan jangka panjang dalam pasar dan membuat masing-masing pihak menerima risiko yang terukur sesuai porsinya.

\section{Pengusaha bioskop}

Berdasarkan Peraturan Menteri Keuangan Nomor PMK 102/PMK.011/2011 tentang Nilai Lain Sebagai Dasar Pengenaan Pajak Atas Pemanfaatan Barang Kena Pajak Tidak Berwujud Dari Luar Daerah Pabean Di Dalam Daerah Pabean Berupa Film Cerita Impor Dan Penyerahan Film Cerita Impor Serta Dasar Pemungutan Pajak Penghasilan Pasal 22 Atas Kegiatan Impor Film Cerita Impor, pengusaha bioskop adalah pelaku usaha perfilman yang menyelenggarakan pertunjukan film di bioskop. Film yang sudah selesai diproduksi akan dinikmati oleh penonton dengan disiarkan melalui layar lebar. Pengusaha bioskop merupakan pihak yang memegang peranan penting dalam proses ekshibisi ini. Kelompok-kelompok bioskop yang ada di Indonesia saat ini adalah Cinema 21, CGV Cinemas (sebelumnya bernama Blitzmegaplex dan CGV Blitz), dan Cinemaxx. Cinema 21 hingga Mei 2018 memiliki total 1003 layar tersebar di 43 kota di 177 lokasi di seluruh Indonesia. ${ }^{2}$ Sampai dengan Januari 2018,

\footnotetext{
${ }^{2}$ Cinema 21, 2018, 21 Cineplex Profile, dalam http://www.21cineplex.com/21 profile, diakses pada tanggal 13 Juni
} 2018. 
CGV Cinemas telah tersedia di 45 lokasi dengan jumlah layar mencapai 288 layar. $^{3}$ Berdasarkan data Pusat Pengembangan Perfilman (Pusbang Film) Kemendikbud (2017: 30), hingga tahun 2016 grup Cinema 21 masih mendominasi jumlah bioskop di Indonesia dengan total kepemilikan bioskop secara nasional dari 259 bioskop, 190 diantaranya dimiliki oleh grup Cinema 21.

\section{Importir film}

Pelaku usaha impor film merupakan badan usaha berbentuk badan hukum Indonesia. Impor film dapat dilakukan oleh perwakilan diplomatik atau badan internasional yang diakui Pemerintah untuk kepentingannya sendiri, dan atas film yang diimpor ini hanya dapat dipertunjukkan kepada khalayak umum dengan pemberitahuan kepada Menteri. Berdasarkan Peraturan Menteri Keuangan Nomor PMK 102/PMK.011/2011 tentang Nilai Lain, importir adalah pelaku usaha perfilman yang melakukan usaha impor film dan/atau pengedaran film. Importir yang aktif dalam menjalankan kegiatan ini adalah MPA (Motion Pictures Association) yang merupakan anak perusahaan dari MPAA (Motion Pictures Association of America). MPA mengimpor film-film dari studio besar seperti Universal, Walt Disney, Paramount dan Sony.

Tahapan kegiatan importasi film cerita impor diawali dengan pembelian hak eksploitasi dari perusahaan film luar negeri. Kopi film cerita impor yang diperoleh akan diserahkan terlebih dahulu kepada distributor untuk kemudian dieksploitasi oleh pengusaha bioskop yang ada di seluruh Indonesia. Skema proses importasi film impor adalah sebagai berikut:

\section{Gambar 1 Skema Proses Importasi Film Impor oleh Importir}

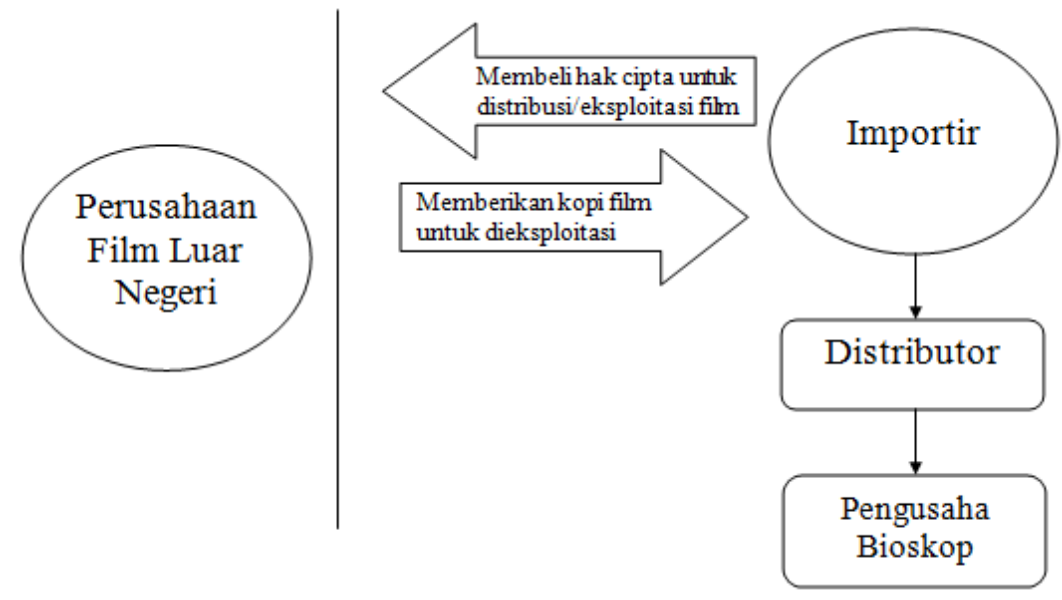

Sumber: Diolah dari Mahira (2012: 62)

Alur distribusi film di Indonesia terdiri dari beberapa fase yang berkembang sejalan dengan kondisi pasar dan kebijakan yang diterapkan terhadap industri perfilman. Pada Fase Distribusi Internal (1998-sekarang), menurut Christian Razukar (Dalam Sasono et.al.,2011: 215), produser film dalam fase ini merupakan uber-capitalist yaitu dalam keadaan yang vakum dari dukungan pemerintah dan di tengah penguasaan pasar distribusi film, produser film berjuang sendirian memproduksi film kemudian memasarkannya. Sebelum beredar dan dipertunjukkan di Indonesia, film dalam negeri dan film impor wajib disensor dan memperoleh surat tanda lulus sensor yang dikeluarkan oleh Lembaga Sensor Film (LSF). Skema penyerahan film dalam negeri dan film cerita impor hingga ditayangkan pada layar bioskop pada fase distribusi internal dapat dilihat pada gambar 2 berikut ini:

\footnotetext{
${ }^{3}$ SWA, 2018, CGV Luaskan Pasar ke Seluruh Indonesia, dalam https://swa.co.id/swa/trends/cgv-luaskan-pasar-
} ke-seluruh-indonesia, diakses pada tanggal 24 Agustus 2018. 


\section{Gambar 2 Skema Penyerahan Film Dalam Negeri dan Film Impor ke Pengusaha Bioskop}

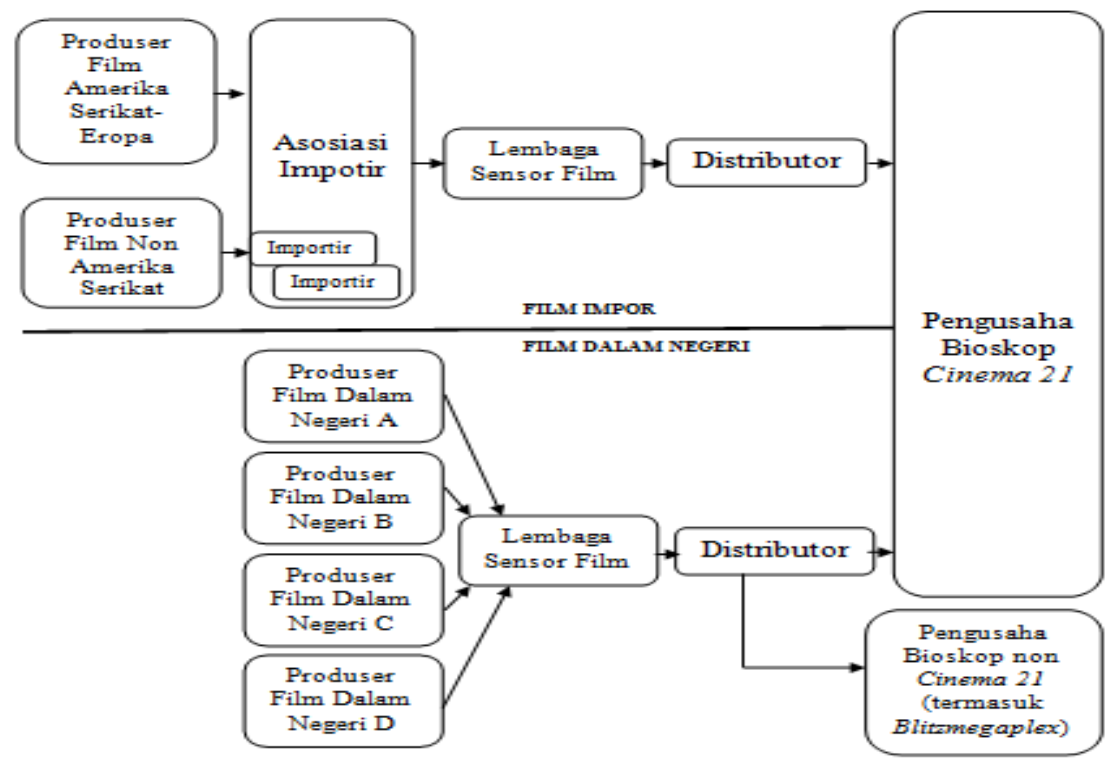

Sumber: Diolah dari Sasono et.al (2011: 216)

\section{Pajak Pertambahan Nilai}

Pajak pertambahan nilai adalah pajak transaksi yang dipungut pada semua tahap produksi dan distribusi. Pajak ini dikenakan atas transaksi barang dan jasa (Thuronyi, 2003, dalam Azizah \& Wijaya, 2020). Adapun Pohan (2016, dalam Wijaya \& Nirvana, 2021) mendefinisikan pajak pertambahan nilai pada hakikatnya merupakan beban konsumen akhir karena mengonsumsi barang atau jasa yang menjadi objek pajak, yang tanggung jawabnya digeserke pihak lain, dalam hal ini pengusaha kena pajak. Sedangkan English (dalam Wijaya \& Sabrina, 2021) mendefinisikan PPN sebagai pajak universal atas kegiatan konsumsi, yang merupakan pajak tidaklangsung yang dibebankan oleh tiap konsumen atastransaksi barang kena pajak ataupun jasakena pajak tertentu.

\section{Beban pajak pertambahan nilai yang ditanggung produser film dalam negeri dan importir film.}

PPN yang terutang terhadap produser film dalam negeri atas kegiatan produksi dan eksploitasi film dalam negeri serta importir film atas kegiatan importasi dan eksploitasi film impor ada yang dapat dikreditkan dan ada yang tidak dapat dikreditkan. Pengenaan PPN yang tidak dapat dikreditkan di dalam penghitungan Pajak Penghasilan (PPh) Badan akhir tahun merupakan biaya atau beban pajak bagi kedua pihak.

Produser film dalam negeri merupakan pihak yang menanggung beban PPN karena di dalam pemanfaatan jasa-jasa selama tahap produksi, produser film dalam negeri membayar nilai jasa termasuk nilai PPN-nya. Beban pajak yang ditanggung oleh produser film dalam negeri adalah PPN yang terutang atas pemanfaatan jasa-jasa tersebut yaitu sebesar pajak masukannya. Kewajiban menyetorkan dan melaporkan PPN yang terutang berada pada pihak yang memberikan jasa-jasa tersebut. Film yang telah selesai diproduksi akan didistribusikan ke pengusaha bioskop. Hasil penjualan tiket atas film-film tersebut merupakan pajak keluaran bagi produser film dalam negeri. Pajak masukan produser film dalam negeri tidak dapat dikreditkan dengan pajak keluarannya disebabkan karena masih diterapkannya penghitungan menggunakan DPP nilai lain berdasarkan Surat Edaran Direktur Jenderal Pajak Nomor SE-30/PJ.3/1987. Berikut merupakan skema perpajakan kegiatan produksi dan eksploitasi film dalam negeri. 
Kegiatan importasi film impor merupakan objek PPN yaitu pemanfaatan BKP tidak berwujud dari luar Daerah Pabean di dalam Daerah Pabean. Penghitungan PPN terutang didasarkan pada DPP nilai lain yaitu Rp12.000.000,00 per kopi judul fim. Film impor yang didistribusikan ke pengusaha-pengusaha bioskop merupakan pajak keluaran importir film dalam kegiatan usahanya yang penghitungannya juga didasarkan pada DPP nilai lain. Pajak masukan bagi impotir film dapat dikreditkan dengan pajak keluarannya sehingga PPN yang terutang adalah nihil dan bukan merupakan beban pajak. Berikut ini merupakan skema perpajakan kegiatan importasi dan eksploitasi film impor.

\section{Gambar 3 Skema Perpajakan Kegiatan Importasi dan Eksploitasi Film Impor}

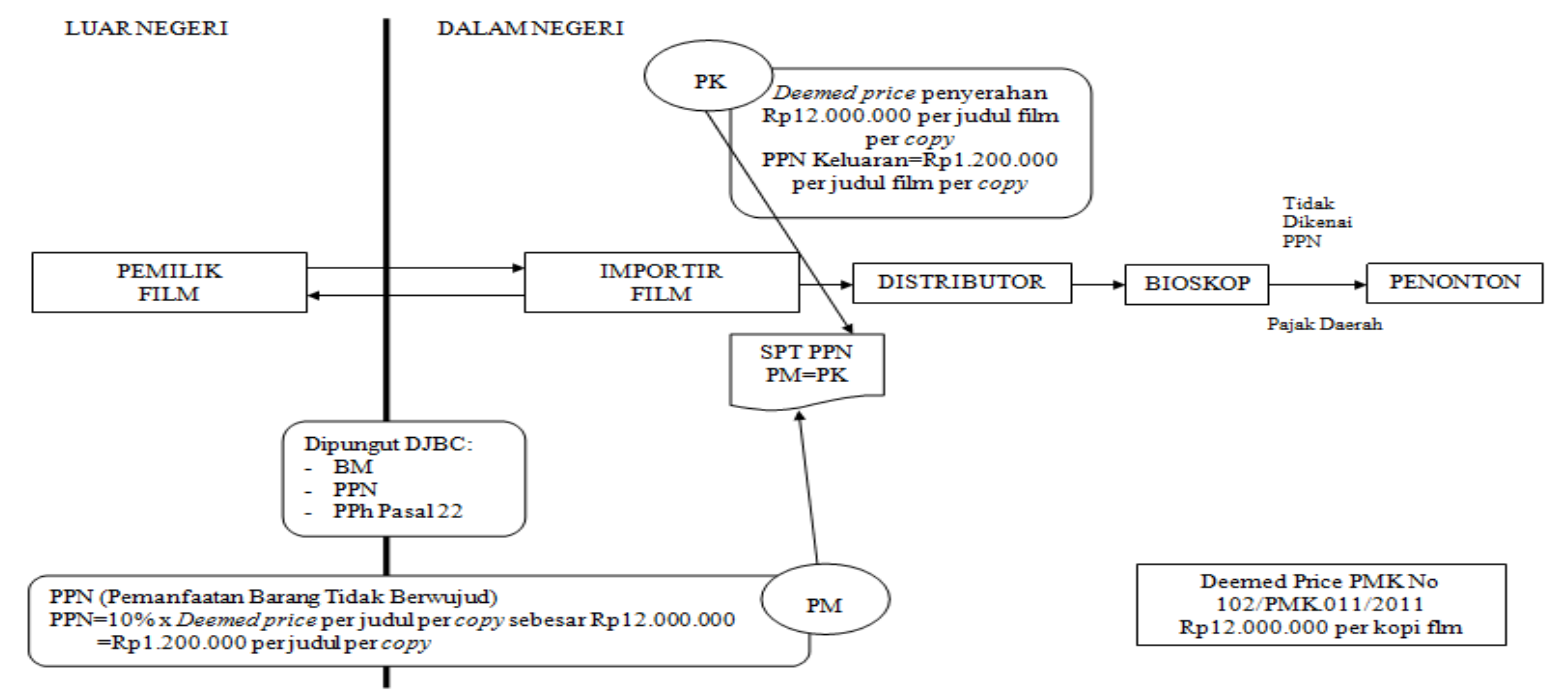

Sumber: Direktorat Jenderal Pajak (dalam Damayanty dan Setiawan, 2017: 52)

\section{METODE}

Metode yang digunakan adalah deskriptif. Firdaus (dalam Wijaya \& Mahatma, 2017) menjelaskan bahwa metode deskriptif digunakan untuk meneliti status suatu objek (dapat berupa manusia, peristiwa, dll). Metode ini dilaksanakan dengan cara mempelajari sejumlah literatur untuk memperoleh dasar teoritis mengenai permasalahan yang akan dibahas. Firdaus (dalam Arkhan \& Rodhiyawan, 2021) lebih jauh menjelaskan bahwa penelitian menggunakan studi literatur, dengan cara mempelajari dan menghimpun data-data atau sumber yang berkaitan terhadap topik bahasan yang diangkat melalui sejumlah literatur yang dapat berupa undang-undang, kajian pustaka, buku, jurnal, berita di media masa dan lainnya. Pendekatan yang digunakan adalah pendekatan positif, yaitu pendekatan yang bertujuan untuk menjelaskan fakta atau praktik yang diamati berdasarkan teori yang telah dipelajari.

\section{HASIL DAN PEMBAHASAN}

\section{Film sebagai barang kena pajak dan industri perfilman di Indonesia}

Berdasarkan penjelasan Pasal 40 Undang-Undang Nomor 28 Tahun 2014 tentang Hak Cipta, karya sinematografi adalah ciptaan yang berupa gambar bergerak (moving images) antara lain film dokumenter, film iklan, reportase, atau film cerita yang dibuat dengan skenario dan film kartun. Karya sinematografi dapat dibuat dalam pita seluloid, pita video, piringan video, cakram optik dan/atau media lain yang memungkinkan untuk dipertunjukkan di bioskop, layar lebar, televisi, atau media lainnya. Kegiatan sinematografi menghasilkan produk keluaran berupa film. Miyarso (2011: 2) menyatakan bahwa "film sebagai karya sinematografi merupakan hasil perpaduan antara kemampuan seseorang atau sekelompok orang dalam 
penguasaan teknologi, olah seni, komunikasi, dan manajemen berorganisasi." Definisi film menurut Undang-Undang Nomor 33 Tahun 2009 tentang Perfilman adalah karya seni budaya yang merupakan pranata sosial dan media komunikasi massa yang dibuat berdasarkan kaidah sinematografi dengan atau tanpa suara dan dapat dipertunjukkan.

Dalam penelitiannya mengenai Bea Masuk dan Pajak-Pajak dalam Rangka Impor (PDRI) Film Impor, Sriyanto (2016: 95) mengutip pernyataan Alan A Tait sebagai berikut.

"Film yang sudah berisi hasil karya cipta dalam bentuk sinematografi menjadikan media rekam menjadi bernilai ekonomis tinggi dibandingkan dengan barang semula/film kosong sehingga tidak bisa menentukan nilai barang hanya dengan menilai harga film permeter karena ada hak cipta yang mengakibatkan timbulnya nilai tambah/value added yang tercermin pada selisih harga penjualan dengan harga pembelian atau the value that producer add to his materials or purchases berfore selling the new or imporved product or service."

Film dengan materi isi yang mengandung hasil karya sinematografi menimbulkan nilai/value yang merupakan bagian dari nilai film tersebut sebagai benda tidak berwujud. Hasil karya sinematografi sebagai salah satu bentuk hak cipta yang terkandung di dalam film menjadikannya bernilai ekonomi lebih tinggi dibandingkan barang semula/film kosong sehingga setiap tambahan kemampuan ekonomis yang diterima atau diperoleh wajib pajak, baik yang berasal dari Indonesia maupun dari luar Indonesia, yang dapat dipakai untuk konsumsi atau untuk menambah kekayaan wajib pajak yang bersangkutan, dengan nama dan dalam bentuk apapun dikenakan Pajak Pertambahan Nilai. Hasil karya sinematografi yang terkandung di dalam film dalam negeri dan film impor yang beredar di Indonesia merupakan bagian dari nilai film tersebut sebagai barang tidak berwujud. Film dalam negeri dan film cerita impor tidak termasuk dalam negative list PPN, maka digolongkan sebagai Barang Kena Pajak.

Undang-Undang Nomor 33 Tahun 2009 tentang Perfilman memberikan definisi film dalam konteks yang cukup menyeluruh. Dijelaskan bahwa (1) film sebagai karya seni budaya berperan strategis dalam peningkatan ketahanan budaya bangsa dan kesejahteraan masyarakat lahir dan batin untuk memperkuat ketahanan nasional oleh karena itu negara bertanggungjawab memajukan perfilman; (2) bahwa film sebagai media komunikasi massa merupakan sarana pencerdasan kehidupan bangsa, pengembangan potensi diri, pembinaan akhlak mulia, pemajuan kesejahteraan masyarakat, serta wahana promosi Indonesia di dunia internasional, sehingga film dan industri perfilman Indonesia perlu dikembangkan dan dilindungi; (3) bahwa film dalam era globalisasi dapat menjadi alat penetrasi kebudayaan sehingga perlu dijaga dari pengaruh negatif yang tidak sesuai dengan ideologi Pancasila dan jati diri bangsa Indonesia; dan (4) bahwa upaya memajukan perfilman Indonesia harus sejalan dengan dinamika masyarakat dan kemajuan ilmu pengetahuan dan teknologi. Berdasarkan keempat hal di atas, Komalawati (2017: 2-3) menyatakan bahwa "negara bertanggungjawab untuk memajukan industri perfilman sejalan dengan kemajuan pengetahuan dan teknologi serta melindungi perfilman dalam negeri dari pengaruh negatif yang tidak sesuai dengan ideologi Pancasila dan jati diri bangsa."

Upaya pemerintah untuk mendukung perkembangan industri perfilman di Indonesia dan melindungi dari pengaruh negatif mencakup seluruh tahapan pada kegiatan ekonomi sebuah film, yaitu pada proses produksi, distribusi, ekshibisi, dan konsumsi media. Pemerintah melalui Pusat Pengembangan Perfilman (Pusbang Film) Kementerian Pendidikan dan Kebudayaan memberikan kemudahan terkait perizinan usaha perfilman, yaitu melalui Elektronik-Daftar dan Izin Perfilman (e-DIF) yang dapat diakses melalui laman Pusbang Film Kemendikbud. Pada aspek produksi, pemerintah dapat mendukung keberlanjutan kegiatan usaha produser film dalam negeri dan importir film dengan mempertegas kepastian hukum pada peraturan perundang-undangan terkait perfilman, insentif fiskal, dan insentif non fiskal. Insentif non 
fiskal yang diberikan dapat berupa pendidikan dan pelatihan terhadap awak film serta kemudahan perizinan produksi dan penggunaan lokasi pembuatan film yang diatur dalam Peraturan Menteri Pariwisata Nomor 2 Tahun 2014 terkait Pelaksanaan Pelayanan Terpadu Satu Pintu (PTSP) bidang pariwisata dan ekonomi kreatif di Badan Koordinasi Penanaman Modal (BKPM). Pada aspek distribusi dan ekshibisi, pemerintah perlu menstimulus perkembangan pengusaha bioskop agar tidak hanya dimonopoli oleh kelompok bioskop tertentu, sehingga film dalam negeri mendapatkan jatah jam penayangan atau pertunjukan yang seimbang dengan film impor. Hal ini tentu perlu diimbangi dengan peningkatan kualitas film dalam negeri sehingga dapat menarik minat penonton. Pada aspek konsumsi, perlu adanya penyuluhan kepada masyarakat melalui media yang tepat sehingga masyarakat mengapresiasi dan bangga terhadap film dalam negeri. Sinergi antara Kemendikbud, Bekraf, BKPM, BPI, dan pelaku industri perfilman di Indonesia diharapkan mampu menghasilkan industri film yang kompetitif dan berkualitas dengan memberikan perlindungan kepada film dalam negeri.

Menurut Bekraf, industri perfilman Indonesia saat ini sedang mengalami perkembangan yang positif. Film, animasi, dan video sebagai salah satu dari 16 sub sektor industri kreatif di Indonesia berpotensi untuk dapat dikembangkan menjadi lebih baik, walapun masih harus menghadapi berbagai kendala. Sebagaimana disajikan pada tabel 1, pada tahun 2015 kontribusi bidang usaha industri film, video, dan fotografi di Indonesia hanya mencapai 0,16 persen dari total PDB. Jumlah ini jauh lebih kecil dari kontribusi industri film dan televisi di Korea Selatan misalnya, yang mencapai KRW 7.549 miliar atau lebih dari Rp83 triliun, ekuivalen dengan 0,7 persen dari total PDB tahun 2011.

Fakta ini tidak selaras dengan berbagai potensi dan peluang yang dapat mendorong perkembangan industri perfilman di Indonesia. Jumlah penduduk Indonesia sebanyak 260 juta jiwa merupakan pasar yang potensial apabila pelaku industri film dalam negeri dapat menjadi tuan rumah di negeri sendiri. Tabel 2 menunjukkan bahwa minat masyarakat untuk menonton film dalam negeri meningkat setiap tahunnya. Film "Pengabdi Setan" pada tahun 2017 mampu menarik 4.206.103 penonton. Dengan asumsi pendapatan Rp37.000 per penonton, maka perkiraan omzet penjualan film "Pengabdi Setan" adalah sebesar Rp155.625.811.000,00. Di sisi lain, omzet yang diperoleh film "Surat Kecil untuk Tuhan" hingga akhir tahun 2017 adalah sebesar Rp26.468.357.000,00. Di samping itu, jumlah film dalam negeri yang mencapai perolehan lebih dari satu juta penonton terus meningkat setiap tahunnya. Berdasarkan data Pusbang Film Kemendikbud (2017: 30) pada tahun 2014, film dalam negeri yang mencapai satu juta penonton hanya 2 film, pada tahun 2015 sebanyak 3 film, pada tahun 2016 sebanyak 10 film, dan hingga bulan Mei 2017 tercatat sebanyak 5 film.

Meskipun jumlah penonton film dalam negeri mengalami tren kenaikan, jumlah tersebut masih lebih rendah dibandingkan dengan jumlah penonton film impor. Tabel 2 menunjukkan bahwa pada tahun 2014 dan 2015, jumlah penonton film dalam negeri relatif stagnan pada kisaran 16 juta penonton. Akan tetapi, jumlah penonton film impor mengalami kenaikan hingga 10 juta penonton, dari 55 juta penonton menjadi 65 juta penonton pada tahun 2015 .

Tabel 2 Perbandingan Data Penonton Film Dalam Negeri dengan Film Impor di Bioskop Tahun 2014-2016

\begin{tabular}{|c|c|c|}
\hline Tahun & Film Impor & Film Dalam Negeri \\
\hline 2014 & 55.558 .049 & 16.319 .804 \\
\hline 2015 & 65.833 .444 & 16.260 .041 \\
\hline 2016 & 65.833 .444 & 16.260 .041 \\
\hline
\end{tabular}

Sumber: Pusbang Film Kemendikbud (2017: 30)

Menurut Bekraf (2016: 7) dalam buku Panduan Pendirian Usaha Film, hal yang juga menjadi daya dukung potensial bagi perkembangan industri perfilman di Indonesia adalah 
besarnya minat para generasi muda untuk berkarya dan bekerja di bidang pembuatan film. Selain itu, keberagaman budaya dan kekayaan geografi di Indonesia dapat dieksploitasi sebagai sumber cerita film. Terlebih lagi dengan dimulainya pasar bebas ASEAN 2015 memberikan peluang bagi industri perfilman di Indonesia untuk lebih luas mendistribusikan film dalam negeri ke seluruh dunia.

Berdasarkan data yang dihimpun oleh Departemen Pendidikan dan Kebudayaan (Dalam Damayanty dan Setiawan, 2017: 50), jumlah film dalam negeri yang beredar di bioskop selama tahun 1999-2016 terus mengalami fluktuasi. Selisih film dalam negeri dan film impor pada tahun 2015 adalah 163 film, sedangkan pada tahun 2016 selisih film dalam negeri dan film impor adalah 85 film. Kondisi ini menunjukkan bahwa meskipun jumlah film dalam negeri belum mampu mengalahkan jumlah film impor yang beredar di bioskop, pilihan tontonan film dalam negeri saat ini semakin banyak di bioskop dan berpotensi untuk dapat bersaing dengan film impor.

Jumlah produksi film dalam negeri dan film impor yang beredar di Indonesia dalam kurun waktu tahun 1999-2016. Damayanty dan Setiawan (2017: 50-51) menyatakan bahwa jumlah produksi film dalam negeri yang secara umum mengalami tren peningkatan setiap tahunnya tidak berkorelasi dengan jumlah produksi film impor. Produksi film dalam negeri mengalami peningkatan di saat film impor mengalami penurunan produksi pada tahun 2008 . Sebaliknya, produksi film dalam negeri mengalami peningkatan pada saat film impor juga mengalami peningkatan produksi pada tahun 2013. Meskipun korelasi ini masih perlu dikaji lebih lanjut, grafik sederhana tersebut setidaknya mengindikasikan bahwa peningkatan produksi film dalam negeri tidak bergantung pada jumlah film impor yang beredar di Indonesia.

Transaksi yang berkaitan dengan kegiatan produksi, importasi, dan eksploitasi film dalam negeri dan film impor yang beredar di Indonesia yang dijalankan oleh produser film dalam negeri dan importir film terutang PPN. Penyerahan film cerita selain film impor ke bioskop dikenakan PPN dengan menggunakan DPP Nilai Lain, yaitu perkiraan hasil rata-rata per judul film sebagaimana diatur dalam PMK Nomor 121/PMK.03/2015 tentang Perubahan Ketiga atas PMK Nomor 75/PMK.03/2010 tentang Nilai Lain sebagai Dasar Pengenaan Pajak. Produser film dalam negeri dapat mengkreditkan pajak masukan dengan pajak keluaran karena dalam peraturan ini penyerahan film dalam negeri bukan termasuk pemanfaatan jasa yang pajak masukannya tidak dapat dikreditkan. Oleh karena itu, beban pajak berupa PPN yang ditanggung oleh produser film dalam negeri tidak terlalu besar jumlahnya. Penghitungan PPN terutang menggunakan Credit Method yaitu PPN yang dibayarkan ke kas negara merupakan hasil pengurangan pajak masukan atas pemanfaatan jasa-jasa dalam proses produksi dengan pajak keluaran atas penyerahan kopi film kepada pengusaha bioskop.

Namun demikian, di dalam pelaksanaannya terdapat amanat Pasal 4 dalam Peraturan Menteri Keuangan Nomor 121/PMK.03/2015 bahwa "Ketentuan lebih lanjut penentuan perkiraan hasil rata-rata per judul film untuk penyerahan film cerita diatur dengan Peraturan Direktur Jenderal Pajak" yang belum dilaksanakan sepenuhnya. Hal ini menyebabkan produser film dalam negeri masih menggunakan SE-30/PJ.3/1987 tentang PPN atas Film Ceritera Produksi Dalam Negeri (Film Nasional). Mahira (2012:82) menyebutkan bahwa pelaku industri film dalam negeri masih menerapkan peraturan lama yaitu SE-30/PJ.3/1987 terutang PPN atas Film Ceritera Produksi Dalam Negeri (Film Nasional) yang sebenarnya sudah tidak berlaku karena telah dikeluarkannya peraturan baru yaitu PMK Nomor 121/PMK.03/2015. Hal ini mengakibatkan tidak dapat dilakukannya pengkreditan pajak masukan yang timbul dari PPN yang harus dibayar produser film dalam negeri atas pemanfaatan jasa-jasa dalam proses produksi film dengan pajak keluaran yang timbul dari penyerahan kopi film dari produser film dalam negeri kepada pihak pengusaha bioskop. Dengan demikian, DPP yang masih digunakan atas penyerahan film dalam negeri adalah deemed price sebesar Rp20.000.000 per judul film. 
Produser film dalam negeri merasa sangat dirugikan karena beban pajak yang ditanggung menjadi lebih besar yaitu berupa PPN sebesar pajak masukannya yang tidak bisa dikreditkan dengan pajak keluaran, mengingat jasa-jasa yang dimanfaatkan berkaitan dengan kegiatan memproduksi film dalam negeri jumlahnya cukup besar.

\section{Penyerahan film sebagai objek pajak pertambahan nilai}

Atas penyerahan film dalam negeri dan film impor di Indonesia serta pemanfaatan barang kena pajak tidak berwujud dari luar daerah pabean ke dalam daerah pabean berupa film impor ke Indonesia dikenakan Pajak Pertambahan Nilai. Pelaku industri perfilman di Indonesia yang melakukan penyerahan film di dalam daerah pabean dan pemanfaatan film impor dari luar daerah pabean dibatasi pada produser film dalam negeri dan importir film.

\section{Produser film dalam negeri}

Kegiatan memproduksi film dalam negeri

Sebuah perusahaan produksi film dalam negeri dalam kegiatan usahanya memiliki berbagai kewajiban perpajakan berkaitan dengan kegiatan-kegiatan yang dilakukannya tersebut. Dalam memproduksi sebuah film, terdapat biaya-biaya yang dikeluarkan untuk memperlancar kegiatan produksi salah satunya adalah pemanfaatan jasa dari pihak lain. Jasajasa tersebut tidak termasuk di dalam jenis jasa yang dikecualikan sesuai yang diatur dalam Pasal 4A ayat 3 UU PPN 1984, sehingga termasuk Jasa Kena Pajak (JKP). Dengan demikian, atas pemanfaatan jasa-jasa tersebut produser film dalam negeri memiliki kewajiban untuk membayar PPN yang terutang. Produser film dalam negeri merupakan pihak yang berkewaijban untuk membayar PPN yang terutang atas pemanfaatan jasa-jasa yang digunakan dalam proses produksi film. PPN yang dibayarkan adalah sebesar $10 \%$ dari nilai atas pemanfaatan jasa kepada pihak yang memberikan jasa-jasa tersebut. PPN yang terutang ini merupakan pajak masukan bagi produser film dalam negeri. Pemanfaatan Jasa Kena Pajak dari Pengusaha Kena Pajak (PKP) terkait kegiatan produksi film antara lain pemakaian lagu, sewa peralatan shooting, jasa teknik untuk editing/animasi/dubbing, jasa sewa lokasi shooting, dan jasa copy film/trailer/color grading/mixing film.

Kegiatan eksploitasi film dalam negeri di Indonesia

Film yang telah selesai diproduksi akan diserahkan oleh distributor kepada pengusaha bioskop untuk dieksploitasi. Pengusaha bioskop berkewajiban untuk membayar PPN sebesar 10\% dari Dasar Pengenaan Pajak (DPP) yang ditentukan oleh peraturan perpajakan yang berlaku. PPN yang terutang atas penyerahan film yang dibayar oleh pengusaha bioskop merupakan pajak keluaran bagi produser film dalam negeri. Atas penyerahan film dalam negeri ke bioskop dikenakan PPN dengan menggunakan DPP Nilai Lain, yaitu perkiraan hasil ratarata per judul film sesuai yang diatur dalam Pasal 2 huruf d Peraturan Menteri Keuangan Nomor 121/PMK.03/2015 tentang Perubahan Ketiga atas Peraturan Menteri Keuangan Nomor 75 /PMK.03/2010 tentang Nilai Lain Sebagai Dasar Pengenaan Pajak. Produser film dalam negeri adalah pihak yang memiliki kewajiban untuk memungut dan menyetorkan PPN yang terutang yang dibayarkan oleh pegusaha bioskop. PPN yang terutang merupakan pajak keluaran bagi produser film dalam negeri.

\section{Importir film}

Terdapat kewajiban perpajakan berkaitan dengan kegiatan-kegiatan usaha yang dilakukan oleh importir film. Rudi Anindito (Dalam Mahira, 2012: 95) menjelaskan bahwa "importir film di dalam melakukan kegiatan mengimpor film impor dan mendistribusikan film impor memiliki beberapa tahapan dalam pelaksanaan kegiatan tersebut." Berikut ini tahapantahapan di dalam kegiatan mengimpor dan mendistribusikan film impor beserta aspek-aspek perpajakan yang terdapat pada setiap tahapnya. 


\section{Kegiatan mengimpor film ke dalam daerah pabean Indonesia}

Perusahaan importir film menghubungi pemilik film di luar negeri untuk membeli rights to distribute atau rights to exploit film yaitu hak untuk mendistribusikan atau mengeksploitasi film impor di Indonesia. Hak ini mengandung nilai royalti di dalamnya dan atas royalti tersebut perusahaan importir film wajib memotong dan memungut PPh Pasal 26 dari pemilik film di luar negeri sesuai yang diatur pada Pasal 26 Undang-Undang Nomor 36 Tahun 2008 tentang Pajak Penghasilan. Pada penelitian terdahulu berkaitan dengan royalti untuk penghitungan bea masuk, salah satunya adalah penelitian yang dibuat oleh Sriyanto (2016:92), dengan simpulan sebagai berikut: (a) Pasal 15 Ayat (1) Undang-Undang Kepabeanan menyatakan bahwa nilai pabean untuk penghitungan bea masuk adalah nilai transaksi dari barang yang bersangkutan. Royalti adalah komponen yang membentuk harga dalam suatu transaksi impor barang sehingga harga yang diberitahukan biasanya sudah termasuk royalti di dalamnya, namun apabila tidak mencantumkan nilai royalti maka royalti tidak diperhitungkan dalam menentukan nilai pabean. (b) Dalam sesi tanya jawab implementasi Agreement on Implementation of Article VII of the GATT 1994 dijelaskan bahwa royalti dan biaya lisensi adalah semua pembayaran yang timbul/diwajibkan sebagai akibat dari penggunaan, pembuatan atau penjualan suatu barang yang memiliki patent, trademark, atau copyright. Keunikan film impor yang berisi content yang mengandung hasil kekayaan intelektual adalah nilai/value yang muncul menjadi bagian dari nilai film impor sendiri sebagai barang tidak berwujud. (c) Bea masuk terhadap royalti film impor hanya akan dikenakan sekali. Ketentuan bea masuk hanya dikenakan apabila benda baik benda berwujud (bergerak dan tidak bergerak) maupun benda tidak berwujud seperti film impor memasuki daerah pabean. (d) Selain royalti terdapat komponen lainnya yang perlu diperhitungkan ke dalam harga bea masuk tersebut, yaitu bagian dari hasil atau pendapatan yang diperoleh importir atas penjualan, pemanfaatan atau pemakaian barang impor yang kemudian disampaikan secara langsung atau tidak langsung kepada pihak MPAA yang tidak ditambahkan pada harga yang sebenarnya atau seharusnya dibayar.

Setelah tercapai kesepakatan antara pemilik film di luar negeri dengan perusahaan importir film, maka kopi film akan dikirimkan kepada perusahaan importir film di Indonesia. Untuk menghitung besarnya bea masuk dan pajak impor sesuai dengan PMK Nomor 160/PMK.04/2010 tentang Nilai Pabean Untuk Penghitungan Bea Masuk yaitu:

Bea masuk $=$ Tarif bea masuk x CIF $(($ harga barang $($ Cost $)$, asuransi

(Insurance) dan ongkos kirim (Freight))

Ketentuan mengenai aspek perpajakan ini diatur pada Undang-Undang Nomor 10 Tahun 1995 tentang Kepabeanan dan Peraturan Menteri Keuangan Nomor 90/PMK.011/2011 tentang Perubahan Kedelapan atas Peraturan Menteri Keuangan Nomor 10/PMK.010/2006 tentang Penetapan Sistem Klasifikasi Barang dan Pembebanan Tarif Bea Masuk Atas Barang Impor berkaitan dengan Bea Masuk Film Impor. Berkaitan dengan PPh Pasal 22 Impor diatur pada Pasal 22 Undang-Undang Nomor 36 Tahun 2008 tentang Pajak Penghasilan. Untuk PPN yang dikenakan atas transaksi masuknya film impor ke dalam daerah pabean Indonesia diatur pada UU PPN 1984 dan untuk Nilai Lain sebagai Dasar Pengenaan Pajaknya diatur pada Peraturan Menteri Keuangan Nomor 102/PMK.011/2011 tentang Nilai Lain Sebagai Dasar Pengenaan Pajak atas Pemanfaatan Barang Kena Pajak Tidak Berwujud dari Luar Daerah Pabean di Dalam Daerah Pabean Berupa Film Cerita Impor dan Penyerahan Film Cerita Impor, Serta Dasar Pemungutan Pajak Penghasilan Pasal 22 Atas Kegiatan Impor Film Cerita Impor.

Kegiatan impor film dari luar negeri yang dilakukan oleh importir merupakan pemanfaatan BKP tidak berwujud dari luar daerah pabean di dalam daerah pabean yang 
termasuk objek PPN sebagaimana diatur dalam Pasal 4 Ayat (1) huruf b dan huruf d UU PPN 1984. Hal ini sesuai dengan salah satu legal karakter PPN yang diterapkan di Indonesia yaitu sistem destination principle atau prinsip negara pengguna barang berupa film impor yang akan dikonsumsi di daerah pabean Indonesia. PPN yang terutang atas kegiatan ini dipungut pada saat impor media film impor.

Sriyanto (2016:101-102) menjelaskan bahwa transaksi impor film yang dilaksanakan oleh importir dan pemilik film atas materi isi kopi film impor merupakan perjanjian lisensi dan distribusi barang. Transaksi yang terjadi adalah pemberian hak (bukan penyerahan hak kepemilikan) kepada importir untuk mengeksploitasi film yang terekam dalam media carriers sebagai medianya. Perjanjian lisensi memiliki karakteristik sebagai berikut: (a) Lisensi hanya dapat dilakukan dengan melalui perjanjian; (b) Penerimanya hanya dapat menggunakan hakhak yang dilisensikan kepadanya, dapat berupa sebagian hak ataupun seluruh hak; dan (c) Suatu lisensi dari pemegang kekayaan intelektual kepada pihak lainnya mengakibatkan diperbolehkannya menggunakan seluruh atau sebagian hak atas kekayaan intelektual kepada pihak lain tersebut, akan tetapi pemegang kekayaan intelektual masih dapat menggunakan hakhak kekayaan intelektual tersebut, artinya hak kekayaan intelektual tersebut tidak berpindah ke pihak lain. Dasar pengenaan pajak yang digunakan untuk menghitung PPN terutang atas film impor adalah nilai lain yang ditetapkan berupa uang sebesar Rp12.000.000,00 per copy film impor sebagaimana yang diatur dalam Peraturan Menteri Keuangan Nomor 102/PMK.011/2011. Besarnya nilai lain ini dapat ditinjau kembali secara berkala yang ditetapkan dengan PMK.

Kegiatan eksploitasi film impor di Indonesia

Importir film yang melakukan penyerahan kopi film impor yang diperoleh kepada pengusaha bioskop memiliki kewajiban untuk memungut PPN. Transaksi ini merupakan penyerahan BKP tidak berwujud di dalam Daerah Pabean oleh pengusaha. Pengusaha bioskop memiliki kewajiban untuk membayar PPN sebesar 10\% dari DPP yang ditentukan oleh peraturan perpajakan yang berlaku. PPN yang terutang atas penyerahan film yang dibayar oleh pengusaha bioskop merupakan pajak keluaran bagi importir film. Dasar Pengenaan Pajak yang digunakan untuk menghitung PPN terutang adalah nilai lain sebagaimana diatur dalam PMK 102/PMK.011/2011. Nilai lain atas penyerahan film cerita impor kepada pengusaha bioskop sama dengan nilai lain pada saat impor, yaitu berupa uang sebesar Rp12.000.000,00 per copy film cerita impor.

PPN yang terutang atas kegiatan importasi film dan eksploitasi film impor wajib dipungut dan disetorkan seluruhnya ke kas negara melalui kantor pos atau bank persepsi dengan menggunakan Surat Setoran Pajak (SSP) oleh orang pribadi atau badan. Subjek pemungut atas kegiatan importasi film adalah Direktorat Jenderal Bea dan Cukai (DJBC), sedangkan subjek pemungut atas kegiatan eksploitasi film impor adalah importir film. PPN yang terutang disetorkan ke kas negara paling lama tanggal 15 bulan berikutnya setelah saat terutangnya pajak. Pada Surat Edaran Direktur Jenderal Pajak Nomor SE-79/PJ/2011 tentang Penyampaian PMK Nomor 102/PMK.011/2011 dijelaskan bahwa PPN atas penyerahan film impor tersebut dipungut pada saat pertama kali masing-masing copy film impor tersebut diserahkan kepada pengusaha bioskop. Atas penyerahan copy film impor, importir wajib menerbitkan Faktur Pajak sesuai dengan ketentuan yang berlaku. Apabila terjadi penyerahan berikutnya atas copy film impor yang sebelumnya telah diserahkan kepada pengusaha bioskop dan telah dipungut PPN kepada pengusaha bioskop lain, maka atas penyerahan tersebut tidak dipungut PPN sehingga tidak perlu diterbitkan Faktur Pajak.

\section{Produser film dalam negeri dan importir film sebagai pengusaha kena pajak}

Pengusaha Kena Pajak adalah orang pribadi atau badan dengan penghasilan bruto dalam suatu Tahun Pajak melebihi batasan tertentu. Batasan penghasilan bruto sesuai yang diatur 
dalam PMK Nomor 197/PMK.03/2013 tentang perubahan atas PMK Nomor 68/PMK.03/2010 tentang Batasan Pengusaha Kecil Pajak Pertambahan Nilai adalah Rp4.800.000.000,00. Orang pribadi atau badan dengan penghasilan bruto lebih dari Rp4.800.000.000,00 wajib dikukuhkan sebagai Pengusaha Kena Pajak, sedangkan orang pribadi atau badan dengan penghasilan bruto kurang dari Rp4.800.000.000,00 merupakan pengusaha kecil dan dapat memilih untuk dikukuhkan sebagai Pengusaha Kena Pajak.

Produser film dalam negeri merupakan subjek PPN atas penyerahan BKP di dalam daerah pabean. Diperkirakan omzet yang diperoleh produser film dalam negeri atas penjualan tiket film "Surat Kecil untuk Tuhan" hingga akhir tahun 2017 adalah sebesar Rp26.468.357.000,00. Jumlah tersebut telah melampaui batasan penghasilan bruto untuk dikukuhkan sebagai Pengusaha Kena Pajak yaitu Rp4.800.000.000,00 sehingga produser film dalam negeri tersebut wajib menjadi Pengusaha Kena Pajak pada tahun berjalan dan menjalankan kewajiban Pengusaha Kena Pajak. Importir film merupakan subjek PPN atas pemanfaatan BKP tidak berwujud dari luar daerah pabean di dalam daerah pabean. Hasil edar atas penjualan tiket film "The Fate of The Furious" pada tahun 2017 adalah sebesar Rp178.831.604.150,00. Jumlah tersebut telah melampaui batasan peredaran penghasilan bruto untuk dikukuhkan sebagai Pengusaha Kena Pajak yaitu Rp4.800.000.000,00 sehingga importir film tersebut wajib menjadi Pengusaha Kena Pajak pada tahun berjalan dan menjalankan kewajiban Pengusaha Kena Pajak.

\section{Struktur biaya dan struktur penghasilan pelaku industri pelaku industri perfilman}

Biaya untuk memproduksi suatu film sangat bervariasi bergantung pada durasi film, kebutuhan honorarium awak film dan ketersediaan peralatan yang diperlukan. Biaya produksi film perlu disesuaikan dengan target penjualan film, kebutuhan modal yang diperlukan, dan berbagai pengeluaran yang telah ditentukan. Dalam proses produksi sebuah film, produser film dalam negeri mengeluarkan biaya atas pemanfaatan jasa-jasa seperti jasa teknik untuk editing/animasi/dubbing; jasa sewa peralatan shooting; jasa mixing film untuk kopi film, trailer, color grading, dan mixing; jasa sewa lokasi shooting; dan jasa pemakaian lagu. Berdasarkan Pasal 4A ayat 3 UU PPN 1984, jasa-jasa tersebut tidak termasuk dalam jenis jasa yang dikecualikan sehingga tergolong sebagai Jasa Kena Pajak (JKP). Oleh karena itu, atas pemanfaatan jasa-jasa tersebut produser film dalam negeri memiliki kewajiban untuk membayar PPN yang terutang.

Film yang telah selesai diproduksi akan diserahkan kepada distributor untuk kemudian dieksploitasi oleh pengusaha bioskop. Distributor memiliki kewenangan dalam menetukan metode yang disepakati untuk mengelola eksploitasi film. Distributor menanggung seluruh biaya produksi dan biaya penggandaan kopi film. Namun, pada prakteknya berdasarkan pendapat yang disampaikan Mira Lesmana (Dalam Sasono et.al., 2011: 196) "nyatanya produser film di Indonesia menanggung sendiri semua resiko produksi dan penayangan filmfilmnya termasuk biaya promosi dan penggandaan." Menurut Sasono et.al. (2011: 191), "hal ini terjadi karena jalur pasar hingga ke ujungnya (ekshibitor) telah dikuasai oleh pihak yang sama/tumpang tindih, sehingga terjadi kecenderungan mnopoli/oligopoli yang kuat."

Produser film dalam negeri memberikan fee atas penyerahan film ke pengusaha bioskop yang dilakukan oleh distributor. Pendapatan yang diperoleh oleh produser film dalam negeri adalah pendapatan bagi hasil dengan pengusaha bioskop setelah dikurangi dengan Pajak Hiburan yaitu sebesar 10 persen. Importir film tidak memiliki struktur biaya yang berkaitan dengan pengenaan pajak pertambahan nilai atas kegiatan usahanya. Pajak masukan impotir film merupakan PPN yang terutang atas kegiatan importasi film impor ke dalam daerah pabean Indonesia. PPN yang terutang dari penyerahan kopi film impor kepada pengusaha bioskop merupakan pajak keluarannya. Pajak masukan bagi impotir film dapat dikreditkan dengan pajak 
keluarannya sehingga PPN yang terutang adalah nihil dan bukan merupakan biaya atau beban pajak.

Setelah memperoleh hak eksploitasi dan kopi film impor dari pemilik film di luar negeri, importir film menyerahkan kopi film impor tersebut kepada distributor yang kemudian akan dieksploitasi oleh pengusaha bioskop. Perusahaan importir memberikan fee atas penyerahan film ke pengusaha bioskop yang dilakukan oleh distributor. Namun, pada prakteknya importir film juga bertindak sebagai distributor sehingga kopi film impor tersebut langsung diserahkan kepada kelompok bioskop yang juga merupakan bagian dari perusahaannya. Pendapatan yang diperoleh oleh impotir film adalah pendapatan bagi hasil dengan pengusaha bioskop setelah dikurangi dengan Pajak Hiburan yaitu sebesar 10 persen. Mekanisme PPN yang terjadi pada film impor tidak menggunakan prinsip pengurangan pajak masukan dan pajak keluaran pada umumnya. Hal ini dikarenakan transaksi dengan pengusaha bioskop berupa pendapatan yang diterima hasil penjualan tiket sudah dikenakan Pajak Hiburan sebagai pajak daerah.

Selain mendominasi peredaran film di Indonesia-seperti yang telah dipaparkan pada poin pembahasan sebelumnya-film impor juga menghasilkan pendapatan yang lebih besar dari peredarannya di Indonesia dibandingkan dengan pendapatan yang dihasilkan dari peredaran film dalam negeri, mengingat jumlah film dalam negeri yang beredar di bioskop tidak sebanyak film impor. Besarnya pendapatan yang diperoleh oleh produser film dalam negeri dan importir film bergantung pada hasil penjualan tiket di bioskop. Namun, yang membedakan antara keduanya adalah film impor memiliki keuntungan karena harga rata-rata tiket film impor di bioskop lebih tinggi dibandingkan dengan harga rata-rata tiket film dalam negeri serta minat masyarakat untuk menonton film impor lebih tinggi dibandingkan dengan film dalam negeri. Dari data yang disajikan terlihat bahwa pendapatan yang diperoleh dari peredaran film impor di Indonesia tahun 2017 dengan judul "The Fate of the Furious" adalah sebesar Rp178.831.604.150,00. Di sisi lain, film "Pengabdi Setan" merupakan film dalam negeri dengan capaian jumlah penonton tertinggi pada tahun 2017 yaitu sebanyak 4.206.103 penonton. Dengan harga rata-rata tiket Rp37.000,00/penonton, maka perkiraan omzet yang diperoleh dari peredaran film ini adalah sebesar Rp155.625.811.000,00. Dengan demikian, berdasarkan kedua data tersebut terlihat bahwa pendapatan yang diperoleh dari hasil edar film impor lebih besar dibandingkan dengan pendapatan yang diperoleh dari hasil edar film dalam negeri.

\section{Beban pajak pertambahan nilai yang ditanggung oleh produser film dalam negeri dan importir film}

Mahira (2012: 89) menyebutkan bahwa dalam suatu perusahaan beban pajak dianggap sebagai biaya (cost) atau beban (expense) yang akan memengaruhi besarnya laba yang diperoleh oleh perusahaan tersebut. Beban-beban pajak yang ditanggung oleh produser film dalam negeri dan importir film ada yang dapat dikreditkan dan ada yang tidak dapat dikreditkan. Beban pajak yang tidak dapat dikreditkan akan menjadi biaya bagi perusahaan yang akan mengurangi penghitungan laba sebelum kena pajak di dalam Laporan Laba Rugi perusahaan sebelum akhirnya didapatkan nilai laba bersih (laba setelah pajak). Penjelasan mengenai halhal apa saja yang menjadi beban pajak pertambahan nilai yang ditanggung oleh produser film dalam negeri dan importir film adalah sebagai berikut.

Beban pajak pertambahan nilai yang ditanggung oleh produser film dalam negeri

Berikut merupakan ilustrasi yang penulis olah dari Mahira (2012: 89-93) untuk mengetahui lebih jelas pengenaan PPN terhadap produser film dalam negeri atas kegiatan produksi dan eksploitasi film dalam negeri. PT Demi Gisela Citra Sinema, salah satu rumah produksi film dalam negeri, memproduksi film yang berjudul "Alangkah Lucunya (Negeri Ini)" pada tahun 2010. Dalam memproduksi film tersebut, PT Demi Gisela Citra Sinema memanfaatkan jasa-jasa untuk membantu proses produksi film. Jasa-jasa yang dimanfaatkan oleh PT Demi Gisela Citra Sinema adalah sebagai berikut: 
- Jasa Sewa Peralatan Shooting

- Jasa Teknik untuk Editing dan Animasi

- Jasa Mixing Film

- Jasa Sewa Lokasi Shooting

- Jasa Pemakaian Lagu

$$
\begin{array}{lr}
=\mathrm{Rp} & 40.000 .000,00 \\
=\mathrm{Rp} & 50.000 .000,00 \\
=\mathrm{Rp} & 100.000 .000,00 \\
=\mathrm{Rp} & 20.000 .000,00 \\
=\mathrm{Rp} & 15.000 .000,00
\end{array}
$$

PT Demi Gisela Citra Sinema berkewajiban untuk membayar PPN sebesar 10\% atas pemanfaatan jasa-jasa tersebut, nilai yang dibayarkan termasuk PPN adalah:

- Jasa Sewa Peralatan Shooting

$=\mathrm{Rp} \quad 44.000 .000,00$

- Jasa Teknik untuk Editing dan Animasi

$=\mathrm{Rp} \quad 55.000 .000,00$

- Jasa Mixing Film

$=\operatorname{Rp} \quad 110.000 .000,00$

- Jasa Sewa Lokasi Shooting

$=\mathrm{Rp} \quad 22.000 .000,00$

- Jasa Pemakaian Lagu

Total

$=\mathrm{Rp} \quad 16.500 .000,00$

$=\mathrm{Rp} \quad 247.500 .000,00$

Setelah proses produksi film selesai, PT Demi Gisela Citra Sinema mendistribusikan film ini ke pengusaha-pengusaha bioskop yang ada di seluruh Indonesia. Penyerahan 20 kopi film yang dilakukan oleh PT Demi Gisela Citra Sinema kepada pihak pengusaha bioskop terutang PPN. PT Demi Gisela Citra Sinema menentukan perkiraan hasil rata-rata dari penjualan tiket atas film "Alangkah Lucunya (Negeri Ini)" adalah Rp225.000.000,00 yang diperoleh dari penghitungan rata-rata tiket yang terjual di 10 bioskop sebanyak 150.000 tiket dengan harga rata-rata sebesar Rp15.000/penonton. Perkiraan hasil rata-rata penjualan ini merupakan nilai sebelum dikurangi Pajak Hiburan dan bagi hasil dengan pengusaha bioskop. Maka penghitungan PPN yang terutang adalah sebagai berikut:

$$
\mathrm{PPN}=10 \% \text { x Rp225.000.000,00 = Rp22.500.000,00 }
$$

Namun demikian, dalam pelaksanaannya di lapangan terdapat ketentuan pada Peraturan Menteri Keuangan Nomor 121/PMK.03/2015 yang belum dilaksanakan sepenuhnya. Produser film dalam negeri masih menggunakan SE-30/PJ.3/1987 tentang PPN atas Film Ceritera Produksi Dalam Negeri (Film Nasional) yang mengatur bahwa DPP nilai lain film cerita adalah sebesar Rp20.000.000 per judul film untuk 30 copy pertama dan Rp1.000.000 untuk tiap copy tambahan serta diatur bahwa pajak masukan atas penyerahan ini tidak dapat dikreditkan. Hal ini disebabkan oleh belum dilaksanakannya amanat Pasal 4 dalam Peraturan Menteri Keuangan Nomor 121/PMK.03/2015 yaitu "Ketentuan lebih lanjut penentuan perkiraan hasil rata-rata per judul film untuk penyerahan film cerita diatur dengan Peraturan Direktur Jenderal Pajak". Dengan tidak dapat dikreditkannya pajak masukan maka produser film dalam negeri harus menanggung beban PPN terutang atas penyerahan film ke bioskop. Penghitungan PPN yang terutang atas penyerahan 20 kopi film kepada pengusaha bioskop adalah sebagai berikut:

$$
\mathrm{PPN}=10 \% \times \mathrm{Rp} 20.000 .000,00 \times 20 \text { kopi film }=\mathrm{Rp} 40.000 .000,00
$$

PPN yang terutang dari transaksi penyerahan kopi film ini merupakan pajak keluaran bagi PT Demi Gisela Citra Sinema.

Penghasilan yang diterima dari peredaran film ke pengusaha bioskop

$$
\begin{array}{lll}
100.000 \text { tiket } x \text { Rp } 15.000,00 & =R p 1.500 .000 .000,00 \\
\text { Pajak Hiburan (10\%) } & =R p \quad 150.000 .000,00 \\
\text { Penghasilan sebelum bagi hasil } & =R p 1.350 .000 .000,00
\end{array}
$$

Pembagian Hasil

Pengusaha Bioskop $\quad: 50 \% x R p 1.350 .000 .000,00=$ Rp675.000.000,00

PT Demi Gisela Citra Sinema: 50\%xRp1.350.000.000,00 = Rp675.000.000,00

Penghasilan yang diterima PT Demi Gisela Citra Sinema
Bagi Hasil
Biaya Produksi
$=\quad \mathrm{Rp} \quad 675.000 .000,00$
Laba Usaha

$$
\begin{array}{lll}
= & R p & 247.500 .000,00 \\
= & R p & 427.500 .000,00
\end{array}-
$$


PPh Badan yang terutang $(25 \%)$

25\% x Rp427.500.000,00 = Rp106.875.000,00

Beban Pajak

- $\mathrm{PPN} \quad=\mathrm{Rp} 22.500 .000,00$

- $\mathrm{PPh}$ Badan $=\mathrm{Rp} \quad 106.875 .000,00+$

Laba Bersih

Rp $\quad 129.375 .000,00$

Berdasarkan ilustrasi diatas, PT Demi Gisela Citra Sinema memperoleh pendapatan sebesar Rp675.000.000,00 setelah bagi hasil dengan pihak bioskop dari hasil penjualan tiket sebanyak 100.000 tiket dengan harga rata-rata Rp15.000,00/penonton. Laba bersih adalah sebesar Rp298.125.000,00 setelah dikurangi dengan total beban pajak sebesar Rp129.375.000,00 berupa PPN dan PPh Badan. Besarnya laba yang diperoleh tidak terlalu tinggi dibandingkan dengan biaya yang dikeluarkan terkait transaksi yang terutang PPN oleh PT Demi Gisela Citra Sinema untuk memproduksi film tersebut yaitu Rp247.500.000,00. Beban pajak yang ditanggung oleh produser film dalam negeri adalah PPN yang terutang dari pemanfaatan jasa-jasa yang digunakan dalam proses produksi yaitu sebesar pajak masukannya. Pajak masukan ini tidak dapat dikreditkan dengan pajak keluarannya yang merupakan PPN terutang dari transaksi penyerahan film kepada pengusaha bioskop, disebabkan karena masih diterapkannya penghitungan menggunakan DPP nilai lain berdasarkan Surat Edaran Direktur Jenderal Pajak Nomor SE-30/PJ.3/1987.

Beban pajak pertambahan nilai yang ditanggung oleh impotir film

PPN yang menjadi pajak masukan bagi perusahaan importir film adalah PPN yang terutang atas kopi film impor pada saat masuk ke dalam Daerah Pabean Indonesia. Sedangkan pajak keluarannya adalah PPN yang terutang dari penyerahan kopi film impor oleh importir film ke pengusaha bioskop untuk dieksploitasi. Apabila pajak masukan lebih besar maka akan terjadi PPN lebih bayar, sebaliknya apabila pajak keluaran lebih besar maka akan terjadi PPN kurang bayar yang harus dibayar oleh impotir film. Apabila besar pajak masukan dan pajak keluaran sama maka PPN yang dibayar nihil. Contoh penghitungan PPN yang terutang terhadap impotir film atas kegiatan usaha yang dilakukannya dapat dilihat pada Lampiran Surat Edaran Direktur Jenderal Pajak Nomor SE-79/PJ/2011 tentang Penyampaian Peraturan Menteri Keuangan Nomor 102/PMK.011/2011 tentang Nilai Lain sebagai Dasar Pengenaan Pajak atas Pemanfaatan Barang Kena Pajak Tidak Berwujud dari Luar Daerah Pabean di dalam Daerah Pabean Berupa Film Cerita Impor dan Penyerahan Film Cerita Impor, serta Dasar Pemungutan Pajak Penghasilan Pasal 22 atas Kegiatan Impor Film Cerita Impor. Berikut merupakan ilustrasi untuk mengetahui lebih jelas pengenaan pajak pertambahan nilai terhadap importir film atas kegiatan importasi dan eksploitasi film impor.

- Impotir film PT A, memiliki Angka Pengenal Impor (API), pada tanggal 8 Juni 2011 memasukkan film impor dalam bentuk pita seluloid dengan judul "XYZ" ke dalam Daerah Pabean dengan durasi 90 menit sebanyak 20 kopi film. Maka penghitungan PPN atas pemasukan film impor tersebut adalah sebagai berikut:

$$
\mathrm{PPN}=10 \% \times \mathrm{Rp} 12.000 .000,00 \times 20=\mathrm{Rp} 24.000 .000,00
$$

Berdasarkan Peraturan Menteri Keuangan Nomor 102/PMK.011/2011 tentang Nilai Lain sebagai Dasar Pengenaan Pajak atas Pemanfaatan Barang Kena Pajak Tidak Berwujud dari Luar Daerah Pabean di Dalam Daerah Pabean berupa Film Cerita Impor dan Penyerahan Film Cerita Impor, serta Dasar Pemungutan Pajak Penghasilan Pasal 22 atas Kegiatan Impor Film Cerita Impor, DPP nilai lain atas pemanfaatan film impor adalah sebesar Rp12.000.000 per kopi film. 
- Pada tanggal 12 Juni 2011, PT A menyerahkan pertama kali 15 kopi film "XYZ" kepada pengusaha bioskop PT B. PT A wajib menerbitkan Faktur Pajak kepada PT B. Penghitungan PPN atas penyerahan film "XYZ" tersebut adalah sebagai berikut:

$\mathrm{PPN}=10 \% \mathrm{x}$ DPP nilai lain $\mathrm{x}$ jumlah kopi film impor

$$
\begin{aligned}
& =10 \% \times \mathrm{Rp} 12.000 .000,00 \times 15 \mathrm{kopi} \\
& =\mathrm{Rp} 18.000 .000,00
\end{aligned}
$$

- Pada tanggal 20 Juni 2011, PT A juga menyerahkan pertama kali 5 kopi film "XYZ" kepada pengusaha bioskop PT C, maka penghitungan PPN atas penyerahan film "XYZ" tersebut adalah sebagai berikut:

$\mathrm{PPN}=10 \% \mathrm{x}$ DPP nilai lain $\mathrm{x}$ jumlah kopi film impor

$$
\begin{aligned}
& =10 \% \times \mathrm{Rp} 12.000 .000,00 \times 5 \mathrm{kopi} \\
& =\mathrm{Rp} 6.000 .000,00
\end{aligned}
$$

Atas penyerahan 5 kopi film, PT A wajib menerbitkan Faktur Pajak kepada PT C.

- Pada tanggal 25 Juni 2011, PT A menyerahkan 5 kopi film "XYZ” yang sebelumnya telah diserahkan kepada pengusaha bioskop PT C, kepada pengusaha bioskop PT D, maka atas penyerahan tersebut tidak terutang PPN. Atas penyerahan 5 kopi film tersebut, tidak perlu diterbitkan Faktur Pajak.

- Atas transaksi-transaksi tersebut di atas, importir film PT A melaporkannya dalam SPT PPN Masa Juni 2011 sebagai berikut:

Pajak keluaran

(Hasil pemungutan PPN kepada bioskop)

Pajak masukan

(PPN yang dibayar pada saat impor)

PPN Kurang/(Lebih) Bayar

$$
=\mathrm{Rp} 24.000 .000,00
$$$$
=\mathrm{Rp} 24.000 .000,00
$$

Beban pajak yang ditanggung oleh importir film adalah pajak masukannya yaitu PPN yang terutang pada saat impor film dari luar daerah pabean. Pajak masukan bagi importir film dapat dikreditkan dengan pajak keluarannya sehingga PPN yang harus dibayar nihil dan bukan lagi merupakan beban pajak bagi importir film. Dari sisi aspek perpajakannya, beban pajak antara film dalam negeri dengan film impor tidak dapat diperbandingkan karena tidak apple to apple. Produser film dalam negeri dikenakan aspek perpajakan sesuai dengan kegiatan memproduksi dan mengeksploitasi filmnya di Indonesia sebagai negara sumber penghasilan dan negara domisili, sedangkan importir film dikenakan aspek perpajakan sesuai dengan kegiatan mengimpor dan mengeksploitasi film impor di Indonesia hanya sebagai negara sumber.

Mahira (2012: 109-110) mengutip pernyataan Darussalam bahwa permasalahan yang terjadi berkaitan dengan aspek perpajakan terhadap produser film dalam negeri dan importir film bukan disebabkan oleh besarnya beban pajak yang ditanggung masing-masing pihak, namun adanya pemahaman yang kurang tepat mengenai hal apa saja yang menjadi beban pajak yang seharusnya mereka tanggung dan apakah sudah terdapat kesesuaian penerapan aspek perpajakan yang berkaitan dengan film dalam negeri dan film impor terhadap ketentuan perpajakan yang berlaku.

\section{PENUTUP}

\section{Simpulan}

Film yang sudah berisi hasil karya cipta dalam bentuk sinematografi menjadikan media rekam mempunyai nilai tambah/value added dibandingkan dengan barang semula atau film kosong, sehingga setiap tambahan kemampuan ekonomis yang diterima atau diperoleh importir film atas pemanfaatan barang kena pajak tidak berwujud dari luar daerah pabean di dalam daerah pabean berupa film impor serta kegiatan mengeksploitasi film cerita di Indonesia; dan 
setiap tambahan kemampuan ekonomis yang diterima atau diperoleh produser film dalam negeri atas kegiatan memproduksi dan mengeksploitasi film dalam negeri serta kegiatan importasi dan eksploitasi film impor dikenakan pajak pertambahan nilai.

Berdasarkan data mengenai jumlah penonton film dalam negeri terlihat bahwa minat masyarakat untuk menonton film dalam negeri meningkat setiap tahunnya. Namun film impor memperoleh pendapatan yang lebih besar dari peredarannya di Indonesia dibandingkan dengan pendapatan film dalam negeri mengingat jumlah film dalam negeri yang beredar di bioskop tidak sebanyak film impor. Berdasarkan hasil telaah atas regulasi yang berlaku saat ini dan kondisi industri perfilman dalam negeri, terdapat peraturan perpajakan yang perlu dipertimbangkan untuk diterbitkan yaitu Peraturan Direktur Jenderal Pajak mengenai DPP Nilai Lain atas penyerahan film dalam negeri yaitu perkiraan hasil rata-rata per judul film sebagaimana yang diatur dalam Pasal 4 Peraturan Menteri Keuangan Nomor 121/PMK.03/2015 tentang DPP Nilai Lain.

Hasil penghitungan perkiraan penghasilan bruto atas penjualan tiket oleh produser film dalam negeri dan importir film menunjukkan bahwa batasan penghasilan bruto sesuai yang diatur dalam PMK Nomor 197/PMK.03/2013 tentang perubahan atas PMK Nomor 68/PMK.03/2010 tentang Batasan Pengusaha Kecil Pajak Pertambahan Nilai telah dilampaui atau melebihi Rp4.800.000.000,00 dalam satu Tahun Pajak sehingga wajib dikukukan sebagai Pengusaha Kena Pajak.

Struktur biaya produser film dalam negeri adalah biaya atas pemanfaatan jasa-jasa untuk memperlancar kegiatan produksi film yang termasuk dalam jasa-jasa yang dikenakan pajak pertambahan nilai sebagaimana diatur dalam Pasal 4A ayat 3 UU PPN 1984. Sedangkan struktur penghasilannya berupa pendapatan yang diperoleh dari bagi hasil dengan pengusaha bioskop atas penjualan tiket di bioskop setelah dikurangi dengan Pajak Hiburan sebagai pajak daerah. Struktur biaya importir film berupa bea masuk, PPh Pasal 21, dan PPh Pasal 26. Sedangkan struktur penghasilannya berupa pendapatan yang diperoleh dari bagi hasil dengan pengusaha bioskop atas penjualan tiket di bioskop setelah dikurangi dengan Pajak Hiburan sebagai pajak daerah.

Beban pajak pertambahan nilai yang ditanggung oleh produser film dalam negeri adalah sebesar pajak masukannya yang terutang dari pemanfaatan jasa-jasa yang digunakan dalam proses produksi. Hal ini disebabkan karena pajak masukan tidak bisa dikreditkan dengan PPN yang muncul dari transaksi penyerahan film kepada pengusaha bioskop yang merupakan pajak keluarannya karena masih diterapkannya Surat Edaran Direktur Jenderal Pajak Nomor SE30/PJ.3/1987.

Tidak terdapat beban pajak pertambahan nilai yang harus ditanggung oleh importir film. Beban pajak berupa PPN yang merupakan pajak masukan bagi perusahaan importir film dapat dikreditkan dengan pajak keluarannya sehingga PPN yang harus dibayar nihil dan bukan lagi merupakan beban pajak bagi importir film. Besarnya beban pajak yang ditanggung oleh produser film dalam negeri dan importir film tidak dapat diperbandingkan. Produser film dalam negeri dikenakan aspek perpajakan sesuai asas domisili dan asas sumber atas kegiatan memproduksi dan mengeksploitasi film dalam negeri di Indonesia, sedangkan importir film hanya dikenakan aspek perpajakan sesuai asas sumber atas kegiatan mengimpor dan mengeksploitasi film impor di Indonesia.

Saran

Pemerintah perlu segera melaksanakan amanat Pasal 4 Peraturan Menteri Keuangan Nomor 121/PMK.03/2015 yaitu menerbitkan Peraturan Direktur Jenderal Pajak yang menetapkan besaran DPP nilai lain untuk penyerahan film dalam negeri ke bioskop agar prinsip pajak keluaran-pajak masukan dapat bekerja. Dengan dibenahinya hal tersebut, diharapkan produser film dalam negeri dapat memperbaiki manajemen arus kas mereka, khususnya atas 
penyerahan film dalam negeri kepada bioskop. Namun, di saat yang sama pemerintah memiliki potensi penerimaan pajak yang lebih besar. Dukungan pemerintah dan pelaku industri perfilman di Indonesia pada setiap kegiatan ekonomi sebuah film. Pemerintah melalui Kemendikbud dan Bekraf bersama pelaku industri perfilman di Indonesia perlu mendukung industri perfilman di Indonesia, baik dari proses produksi, distribusi, ekshibisi, dan konsumsi media film.

Pemberian insentif non fiskal melalui fasilitas pendidikan dan pelatihan bagi pelaku industri perfilman. Pendidikan dan pelatihan dilakukan untuk meningkatkan kemampuan para kru film Indonesia, sehingga dapat menghasilkan film-film yang berkualitas sekaligus diminati oleh publik. Hal ini dapat dilakukan dengan memberikan beasiswa dari pemerintah atau lembaga independen kepada para kru film termasuk sutradara. Selain itu, upaya yang juga dapat dilakukan adalah dengan mengembangkan workshop, diskusi, dan memberikan ruang pada sineas jalur kiri (sidestream) atau film-film independen karya anak bangsa. Dengan upaya ini diharapkan film Indonesia dapat menjadi tuan rumah di negaranya sendiri.

Kemudahan perizinan produksi dan penggunaan lokasi untuk pembuatan film bagi produser film dalam negeri dan importir film. Perizinan produksi industri perfilman di Indonesia telah diatur dengan peraturan yang berlaku dan dikoordinasi oleh BKPM. Dengan adanya kemudahan dalam perizinan penggunaan lokasi pembuatan film, secara tidak langsung dapat mendorong pertumbuhan perekonomian di lokasi pembuatan film sekaligus sebagai ajang promosi sektor pariwisata Indonesia.

\section{DAFTAR PUSTAKA}

Alkhajar, E. N. S. (2010). Masa-Masa Suram Dunia Perfilman Indonesia (Studi Periode 19571968 dan 1992-2002). Jurnal Komunikasi Massa. Vol.3.

Ardiyono, Y. (2015). Perkembangan Motif Sineas Film Indie Dalam Menghadapi Industri Film Mainstream. The Messenger. Vol. 7.

Arkhan, R. F., \& Rodhiyawan, W. W. (2021). Pengenaan Pajak Pertambahan Nilai Terhadap Jasa Penyelenggaraan Seminar. Educoretax, 1(2), 143-153. Diambil dari https://jurnalku.org/index.php/educoretax/article/view/15

Azanda, S. H. (2012). Kebijakan Pajak Pertambahan Nilai Atas Film Impor. Fakultas Ilmu Sosial dan Ilmu Politik, Program Studi Ilmu Administrasi Fiskal, Universitas Indonesia.

Azizah, W. N., \& Wijaya, S. (2020). Overview Of Income Tax on More VAT Differences in Retail Used Motorcycle Retail. Dinasti International Journal of Economics, Finance \& Accounting, 1(1), 134-145

Badan Ekonomi Kreatif. (2016). Panduan Pendirian Usaha Film. Jakarta: Badan Ekonomi Kreatif.

Badan Ekonomi Kreatif. (2017). Data Statistik dan Hasil Survey Ekonomi Kreatif Kerjasama Badan Ekonomi Kreatif dan Badan Pusat Statistik. Jakarta: Badan Ekonomi Kreatif.

Damayanty, S. A. \& Setiawan, H. (2017). Dukungan Fiskal Bagi Industri Film Indonesia. Jakarta: Badan Kebijakan Fiskal.

Handayani, Y. (2015). Mengembalikan Kejayaan Perfilman Indonesia Melalui Penyempurnaan Undang-Undang Perfilman. Jurnal Rechtsvinding.

Komalawati, E. (2017). Industri Film Indonesia: Membangun Keselarasan Ekonomi Media Film dan Kualitas Konten. Jurnal Komunikasi. Vol.1.

Mahira, A. A. (2012). Analisis Beban Pajak Atas Film Nasional dan Film Impor Bagi Produser dan Importir. Fakultas Ilmu Sosial dan Ilmu Politik, Program Studi Ilmu Administrasi Fiskal, Universitas Indonesia.

Miyarso, E. (2011). Peran Penting Sinematografi Dalam Pendidikan Pada Era Teknologi Informasi \& Komunikasi. Majalah Pendidikan. 
Pusat Pengembangan Perfilman Kementerian Pendidikan dan Kebudayaan. (2017). Warta Sinema Cerdas: Melalui Film. Edisi ke-2. Jakarta: Pusat Pengembangan Perfilman Kementerian Pendidikan dan Kebudayaan.

Sasono, E. (2011). Menjegal Film Indonesia Pemetaan Ekonomi Politik Industri Film Indonesia. Jakarta: Rumah Film.

Suwardi, A. K. (2017). Studi Kasus Distribusi Film Independen Oleh Buttonijo. Fakultas Ilmu Sosial dan Ilmu Politik, Program Studi Ilmu Komunikasi, Universitas Airlangga.

Sriyanto, A. (2016). Tinjauan Yuridis Pengenaan Bea Masuk dan Pajak-Pajak dalam Rangka Impor (PDRI) Film Impor. Jurnal Informasi Keuangan dan Akuntansi, Vol. 3.1.

Wijaya, S., \& Mahatma, E. A. (2017). Analisa Upaya Peningkatan Penerimaan Perpajakan dari Penggalian Potensi Pajak Atas Penghasilan Youtuber. Jurnal Manajemen Keuangan Publik, 1(2), 125-130.

Wijaya, S., \& Nirvana, A. P. (2021). Pajak Pertambahan Nilai Perdagangan Melalui Sistem Elektronik (Studi Kasus PT Shopee Internasional Indonesia). Bilancia: Jurnal Ilmiah Akuntansi,5(3), 245-256.

Wijaya, S., \& Sabina, D. I. A. (2021). Reformulasi Pengkreditan Pajak Masukan Pasca Omnibus Law. Jurnal Pajak Indonesia (Indonesian Tax Review), 5(1).

Badan Ekonomi Kreatif. 2017. Film, Animasi, dan Video. Dalam http://www.bekraf.go.id/subsektor/page/film-animasi-dan-video

Badan Perfilman Indonesia. (2017). Tentang Badan Perfilman Indonesia. Dalam https://www.bpi.or.id/tentang.html

Box Office Mojo. (2018). Indonesia Box Office Index. Dalam http://www.boxofficemojo.com/intl/indonesia/

Film Indonesia. (2018). Data Penonton. Dalam

http://filmindonesia.or.id/movie/viewer/

Kamus Besar Bahasa Indonesia. (2018). Arti kata sinematografi. Dalam https://kbbi.web.id/sinematografi

Ramadani, D. (2013). Risalah 2012: Jumlah Bioskop Bertambah, Harga Tiket Naik. Dalam http://filmindonesia.or.id/article/risalah-2012-jumlah-bioskop-bertambah-harga-tiketnaik\#.Wz51BsIyXIU 